\title{
Fungal laccases as biocatalysts for wide range applications
}

\author{
Felipe de Salas and Susana Camarero* \\ Centro de Investigaciones Biológicas, CSIC. Ramiro de Maeztu 9, 28040 Madrid, Spain \\ *Correspondence to: susanacam@cib.csic.es \\ fsalas@cib.csic.es
}

\begin{abstract}
Fungal laccases are multicopper oxidases with high catalytic versatility and low catalytic requirements (only $\mathrm{O}_{2}$ of the air is required for activation). Their high redox potential, especially of certain basidiomycete laccases, significantly increases their oxidation capacity compared to bacterial laccases. These characteristics together provide these enzymes with great potential for applications as biocatalysts in a range of synthetic or degrading reactions. We review here some of the main properties and biotechnological applications of fungal laccases, underlining their overexpression limitations for industrial scale application. We focus on the use of laccases as biocatalysts for organic synthesis, with special emphasis on polymer synthesis.
\end{abstract}

\section{Keywords}

Laccase, fungi, basidiomycetes, catalytic activity, heterologous expression, white biotechnology, organic synthesis, polymerization, polyaniline. 


\section{General aspects of laccases}

Laccases are phenol oxidases (EC 1.10.3.2) belonging to the multicopper oxidases (MCO) superfamily. Discovered in 1883 in the exudates of the lacquer tree Toxicodendron vernicifluum (Yoshida, 1883), laccases have been isolated from plants, fungi (ascomycetes, basidiomycetes and deuteromycetes), prokaryotes and arthropods, where they are involved in different biological processes. Fungal laccases are implicated in intra- and extracellular physiological processes including morphogenesis, pigmentation, pathogenesis, delignification and detoxification (Claus, 2004; Hoegger et al., 2006; Morozova et al., 2007). White-rot basidiomycetes, responsible for wood decay in nature, are among the main laccase producers together with the litter-decomposing fungi. They secrete laccases as part of an array of oxidoreductases, with ligninolytic peroxidases as the main players, enabling the efficient biodegradation of the lignin polymer (Eggert et al., 1996; Lundell et al., 2010).

Fungal laccases are mainly monomeric extracellular proteins although some basidiomycete (e.g. Pleurotus ribis, Pleurotus pulmonarius, Trametes villosa, Cantharelus cibarius) or ascomycete laccases (Rhizoctonia solani) consist of homodimers with each subunit with $\mathrm{M}_{\mathrm{W}}$ similar to monomeric laccases (Morozova et al., 2007). Laccases typically fold in three cupredoxin-like domains, each of them with a typical $\beta$-barrel topology. The protein structure is stabilized by two disulfide bonds, one located between domains one (D1) and three (D3), and the other between domains one (D1) and two (D2) (Fig. 1) (Rivera-Hoyos et al., 2013; Hakulinen and Rouvinen, 2015).

<Figure 1 near here>

Laccases present four copper ions in the active site that act as cofactors for their catalytic activity. Depending on their UV/visible and electron paramagnetic resonance (EPR) spectroscopy properties, these copper ions are classified as follows: Type 1 (T1) copper, EPR detectable and with a strong absorption at $600 \mathrm{~nm}$, is responsible of the blue color of laccases; Type 2 (T2) copper, colorless but detectable by EPR; and a pair of type 3 (T3) copper ions, with no EPR signal due to an antiferromagnetic coupling mediated by a bridging hydroxyl ligand, and weak absorbance at $330 \mathrm{~nm}$ (Jones and Solomon, 2015). The T2 and T3 coppers form the tri-nuclear cluster (TNC) where $\mathrm{O}_{2}$ is reduced to water by the four electrons taken from four molecules of substrate at the T1 site (Sekretaryova et al., 2019). T1 site is located in the D3 of the protein, while the tri-nuclear cluster (T2/T3) is embed between D1 and D3 with both domains providing residues for the coordination of the three coppers (arranged in a regular triangle). The T1 copper is coordinated by one Cys and two His. In the TNC, each of the T3 coppers have three His ligands and both are connected by an $\mathrm{OH}$ bridge, while the T2 copper is coordinated by two His (Jones and Solomon, 2015). The highly 
conserved Cys-His superexchange pathway (around $13 \AA$ ) serves as via to transfer the electrons from T1 site to the TNC (Fig. 2) (Piontek et al., 2002; Jones and Solomon, 2015). A conserved Asp residue (Asp 206 according to PM1 numbering) assists with His ligand (His455 according to PM1 laccase numbering) to the concerted electroproton transfer at the T1 site (Galli et al., 2013). Besides there are two conserved acid residues (Asp 77 and Asp 453 according to PM1 laccase numbering) located close to the TNC that have a crucial role in $\mathrm{O}_{2}$ reduction by aiding $\mathrm{O}_{2}$ binding and providing protons (favored at acid pH) (Jones and Solomon, 2015).

$<$ Figure 2 near here>

According to the reduction potential of the T1 site, laccases can be classified as low (LRPLs, $E^{0}<+500 \mathrm{mV}$, most plant and prokaryotic laccases), medium (MRPLs, $E^{0}+500$ to around $+700 \mathrm{mV}$ ) and high (HRPLs, $E^{0}$ from +720 to $+800 \mathrm{mV}$ ) redox potential laccases (Pardo and Camarero, 2015a). The latter are mainly produced by the whiterot, and litter-decomposing basidiomycete fungi and are of great biotechnological interest due to their high oxidation versatility (Hoegger et al., 2006). These dramatic changes in laccase's redox potential are attributed to a perturbation in the geometry of the T1 site (Augustine et al., 2008) that is in part modulated by the presence of a Met as the axial ligand in plant and bacterial laccases. The distorted tetrahedral geometry of the latter enzymes is replaced by a trigonal planar geometry in fungal laccases (MRPLs and HRPLs) with a non-coordinating residue (Leu or Phe) in the axial position (Hakulinen et al., 2002; Piontek et al., 2002). The influence of the axial amino acid in T1 redox potential has been demonstrated in several studies (Hall et al., 1999; $\mathrm{Xu}, 1999$ ). For instance, substitution of the axial ligand Met 502 in CotA laccase from Bacillus subtilis ( $E^{0}=455 \mathrm{mV}$ ) by non-coordinating Leu or Phe increases $E^{0}$ to 515 or $548 \mathrm{mV}$, respectively (Durão et al., 2006).

Eukaryotic laccases show molecular masses between 60-130 kDa of which 10-50\% may be attributed to glycosylation, mainly $\mathrm{N}$-glycosylation (Xu et al., 2019). Nglycosylation takes place in the lumen of the endoplasmic reticulum and is finalized in the Golgi (Burda and Aebi, 1999; Herscovics, 1999), and might influence secretion, proteolytic susceptibility, catalytic activity or thermal stability of laccases (Madhavi and Lele, 2009).

Laccases are capable to oxidize a wide range of different compounds, preferably $o$ and $p$-substituted phenols and aromatic amines, together with N-heterocycles (indole, benzothiazol, tetrahydroquinoline, hydroxyphthalimide, naphthol, etc), heterocyclic thiols, as well as some inorganic/organic metals. The oxidation of these compounds only requires $\mathrm{O}_{2}$ from the air as electron acceptor and produces water as sole-by product (Gianfreda et al., 1999; Polak and Jarosz-Wilkolazka, 2012; Mogharabi and 
Faramarzi, 2014). The promiscuous activity and low catalytic requirements turn laccases in biocatalysts of choice for many different applications.

\section{Catalytic site and reaction mechanism of laccases}

The catalytic cycle starts with the oxidation of the substrate at the T1 site. It is assumed that laccase acts as a battery, storing the electrons from four monovalent oxidation reactions, which are transferred from the T1 site to the TNC to reduce one $\mathrm{O}_{2}$ molecule to two $\mathrm{H}_{2} \mathrm{O}$ molecules (Jones and Solomon, 2015). Consequently, the enzyme is transformed from the resting oxidized state into the fully reduced state (Fig. 3). Then, the interaction of the TNC with $\mathrm{O}_{2}$ proceeds in two consecutive steps. In the first one, two electrons, one from the $\mathrm{T} 2 \mathrm{Cu}$ and the other from one of the $\mathrm{T} 3 \mathrm{Cu}$ ions of the fully reduced enzyme are donated to the molecular $\mathrm{O}_{2}$ generating the peroxy intermediate. In the second step, the bond 0-0 is broken with the donation of two more electrons from the T1 and T3 copper sites, rendering the fully oxidized native intermediate (NI) of the laccase. A proton transfer, required for the reduction of molecular $\mathrm{O}_{2}$ to water in the TNC, takes place at the same time as the electron transfer. The total reduction of NI by the oxidation of a new set of substrate molecules and the release of two water molecules will start a new catalytic cycle or, in case of lack of more substrate, the slow decay to the resting oxidized form will take place (Yoon and Solomon, 2007; Jones and Solomon, 2015).

<Figure 3 near here>

\section{Laccase mediator systems}

The oxidation capabilities of laccase can be enhanced in the presence of low molecular weight compounds that act as redox mediators once oxidized by the enzyme. In the so-called laccase mediator systems (LMS), the oxidized mediator ("stabilized radical") acts as a diffusible electron carrier, overcoming steric hindrances, to enable the oxidation of bulky substrates such as lignin, cellulose or starch polymers inaccessible to the enzyme, or of substrates with higher redox potentials that are not oxidized by the enzyme alone (Baiocco et al., 2003; Camarero et al., 2004; Kunamneni et al., 2008; Cañas and Camarero, 2010). The 2,2'-azinobis(3-ethylbenzothiazoline-6-sulfonic acid) (ABTS), was the first compound described in the 1990's as laccase redox mediator for the enzymatic oxidation of non-phenolic lignin model compounds and the delignification and bleaching of paper pulps (Bourbonnais and Paice, 1990, 1992). Since then, the ability of other synthetic compounds such as 1-hydroxybenzotriazole (HBT), violuric acid, or 2,2,6,6-tetramethylpiperidine 1-oxyl (TEMPO) to act as redox mediators of laccases has been demonstrated in a range of oxidation reactions of target compounds (Call and Mücke, 1997; Galli and Gentili, 2004; Xu et al., 2009; Benzina et al., 2012; Rostami et al., 2018). Due to the different oxidation mechanisms, 
the use of different mediators may lead to different products (Baiocco et al., 2003). Ultimately, the use of mediators adds to the enzyme higher versatility as biocatalyst.

The industrial application of LMS has, however, two main obstacles: the elevated cost of synthetic mediators and the possible generation and discharge in the industrial effluents of toxic intermediates. Substitution of synthetic mediators by low-cost natural mediators obtained from renewable sources constitute an efficient, ecofriendly and sustainable alternative for the application of LMS in white biotechnology processes. This is the case of certain phenolic compounds derived from lignin polymer that can be obtained as bio-products from the same industrial processes of biomass conversion in which laccases could be implemented (e.g. wood pulping and pulp bleaching). These natural phenolic compounds have been successfully assayed as laccases mediators in dye decolorization, detoxification of aromatic pollutants, pitch removal, delignification and bleaching of paper pulps or to enhance saccharification in biofuel production (Camarero et al., 2005, 2007, 2008; Cañas et al., 2007; Gutiérrez et al., 2007; Kunamneni et al., 2008; Cañas and Camarero, 2010; Babot et al., 2011; Hollmann and Arends, 2012; Rico et al., 2014; Pardo and Camarero, 2015b).

\section{Heterologous expression of fungal laccases}

Enzyme overexpression is mandatory for its commercialization as industrial biocatalyst, and constitutes a challenging task in the case of basidiomycete laccases. Examples of overproduction of wild basidiomycete laccases are barely found in the literature. One outstanding example is the gram-scale production $\left(1.5 \mathrm{~g} \mathrm{l}^{-1}\right)$ of $P$. cinnabarinus wild type laccase by the monokaryotic Pyconoporus cinnabarinus ss 3 strain using ethanol as inducer (Lomascolo et al., 2003). The homologous overproduction of the recombinant native laccase was later achieved $\left(1.2 \mathrm{~g} \mathrm{l}^{-1}\right)$ by transforming a laccase-deficient $P$. cinnabarinus monokaryotic strain with the $P$. cinnabarinus laccase gene under the control of Schizophyllum commune glyceraldehyde-3-phosphate dehydrogenase (GAPDH) promoter (Alves et al., 2004). The homologous overexpression of laccase III from Coriolus (Trametes) versicolor under control of the GAPDH promoter was also reported, although no enzyme yields were informed (Kajita et al., 2004). Homologous expression of Coprinus cinerea lcc1 under the control of various homologous and heterologous promoters was proved as well, obtaining also the highest laccase activity ( $3 \mathrm{U} \mathrm{ml}^{-1}$ with ABTS) with the promoter of GAPDH from Agaricus bisporus (Kilaru et al., 2006).

The difficult genetic manipulation of the natural production strains, together with the lack of GRAS (generally recognized as safe) status and optimized scale-up protocols for industrial fermentation of wild laccases, discouraged the use of basidiomycete 
strains to engineer and produce laccases so far, drawing the attention to heterologous expression hosts (Otterbein et al., 2000). To this end, optimization of laccase CDS according to the codon usage of the heterologous host, selection of adequate expression vectors and signal peptides and optimization of the expression conditions are carried out with dissimilar results.

The bacterium Escherichia coli is successfully used for the expression, engineering and scale up production of bacterial laccases (Alessandra et al., 2010; Hämäläinen et al., 2018), but the effective expression of active fungal laccases in bacteria has not been achieved so far, most likely due to differences in their post-translational processing machineries (Salony et al., 2008; Ma et al., 2018).

By contrast, ascomycete expression systems (both yeasts and filamentous fungi), well established for the industrial production of eukaryotic enzymes, are well suited as heterologous hosts for the functional expression of basidiomycete laccases. However, the levels of basidiomycete enzymes produced in these systems are often much lower than those of ascomycete enzymes. Some of the reasons behind this fact may be: i) the disparities in basidiomycete and ascomycete gene models (basidiomycete genes often have more introns with less conserved start and stop sequences), ii) the sensitivity of basidiomycete laccases to ascomycete proteases iii) the induction of the repression under secretion stress (RESS) mechanism which downregulates the transcription of genes encoding secreted proteins or iv) the activation of mRNA-destabilizing proteins which may affect the heterologous mRNA stability, thereby diminishing the production of heterologous proteins (Su et al., 2012; Casado López et al., 2016).

The low expression yields and frequent hyperglycosylation of recombinant proteins hinder the use of the yeast Saccharomyces cerevisiae as industrial host (Herscovics, 1999), whereas the powerful methanol-inducible alcohol oxidase (AOX1) promoter and the high-density growth of the yeast Pichia pastoris (up to $\mathrm{OD}_{600}=500$ in bioreactor) provide, in general, higher enzyme yields. Conversely, variable enzyme expression yields are obtained depending on the characteristics of the heterologous protein, which makes this expression system weakly predictable (Cereghino, 2002; Mate et al., 2013; Wang et al., 2016). The highest enzyme yields ever reported (550 $\mathrm{mg} \mathrm{l}^{-1}$ ) for a basidiomycete laccase produced in P. pastoris in fed-batch fermentation corresponds to T. versicolor laccase using AOX1 promoter (Hong et al., 2002). Constitutive promoters such as the GAPDH have also been assayed. That is the case of fed-batch fermentation of $P$. pastoris producing POXA1b laccase (from the basidiomycete Pleurotus ostreatus), where constitutive production under GAPDH outperformed the enzyme levels obtained in AOX-induced cultures (Pezzella et al., 2017). This is in agreement with results obtained with the ascomycete Botrytis aclada laccase (Kittl et al., 2012), where the enzyme levels were about 40-60 $\mathrm{mg} \mathrm{l}^{-1}$. 
Replacement of the native laccase signal peptide by the $S$. cerevisiae $\alpha$-factor signal sequence is frequently applied to increase the production of the recombinant enzyme by yeast. This approach was successfully used to express, for instance, two laccases from the white-rot fungus Physisporinus rivulosus in P. pastoris (Hildén et al., 2013). Moreover, the directed evolution of the laccase encoding sequence fused to the $\alpha$ factor pre proleader was successfully used in several enzyme engineering works to increase the secretion of fungal laccases by S. cerevisiae (Bulter et al., 2003; Mate et al., 2010; Camarero et al., 2012; Pardo et al., 2012). This strategy has recently rendered outstanding laccase production yields in S. cerevisiae (25 $\mathrm{mg} \mathrm{l}^{-1}$ ) in our laboratory (de Salas et al., 2019a).

Among all the host systems used for protein expression, filamentous fungi show the highest expression levels especially when the secreted protein is homologous or is from fungal origin. Even if the genetic manipulation of filamentous fungi is more complex than that of yeasts, the high expression yields of active enzyme and the low cost of the growth media (filamentous fungi show enormous nutrition flexibility) make them the preferred hosts for production of industrial enzymes (Fig. 4). There are several examples of basidiomycete laccases heterologously expressed in Aspergillus, Trichoderma or Penicillium (Abianova et al., 2010). The highest expression yields (close to gram per liter) have been reported in Aspergillus (Couto and TocaHerrera, 2007; Alessandra et al., 2010). For instance, gram-scale production of a laccase from Trametes sp. C30 has been achieved in A. niger (Mekmouche et al., 2014). The heterologous production of other native basidiomycete laccases and their variants engineered in vitro has also been attained in this species although at a lower scale, i.e. $P$. cinnabarinus wild-type laccase (145 $\mathrm{mg} \mathrm{l}^{-1}$, Record et al., 2002) and an evolved variant (23 $\mathrm{mg} \mathrm{l}^{-1}$, Camarero et al., 2012), and wild-type P0XA1b and its 1H6C variant (13 $\mathrm{mg} \mathrm{l}^{-1}$ and $20 \mathrm{mg} \mathrm{l}^{-1}$, respectively, Macellaro et al., 2014). Aspergillus oryzae is the preferred host for producing industrial enzymes at Novozymes (world leader company in commercializing industrial enzymes), such as the high-redox potential laccase from T. villosa commercialized as NS 51002 (no longer available) and the ascomycete Myceliophtora thermophila laccase (NS 51003). This expression system has been used for the overexpression of basidiomycete laccase variants developed in our lab by directed evolution to an industrial relevant scale in Novozymes (De Salas et al., 2016; de Salas et al., 2019b).

<Figure 4 near here>

Enzymes can substitute chemical catalysts in diverse reactions providing the advantages of less toxicity than chemical catalyzers and increasing the selectivity in some cases. Nevertheless, the frequent demanding conditions of the industrial processes (extreme $\mathrm{pH}$, high temperature, presence of co-solvents or inhibitors, etc.), the recalcitrance of some substrates or selectivity requirements are main hurdles for 
the application of wild-type enzymes in industrial processes. Therefore, the engineering of the enzyme is frequently required to adjust the activity and stability of the enzyme to the operation conditions or to design new or improved activity or selectivity towards specific substrates. Although this step, together with the aforementioned overexpression of the enzyme, is indispensable to apply laccases at industrial scale, this is not within the objectives of this chapter, and there are other reviews dealing with this subject (Kunamneni et al., 2008; Gonzalez-Perez et al., 2012; Pardo and Camarero, 2015b).

\section{Biotechnological applications}

Laccases, alone or in LMS, are multipurpose biocatalysts with application in a wide range of industrial processes (Fig. 5).

Fungal laccases are commercialized as industrial enzymes by Novozymes (Denmark), Jena Biosciences (Germany), Creative Enzymes (USA), Ecostar (India), USBiological (USA), ASA Spezialenzyme (Germany), etc. Bacterial laccases are produced and commercialized by MetGen (Finland). So far, there are quite a few successful cases of laccases formulated and commercialized for target-applications: Denim fabric finishing (DeniLite ${ }^{\circledR}$ ), paper pulp delignification and bleaching (Novozyme NS-51003, MetZyme $^{\circledR}$ LIGNO $\left.^{\text {TM}}\right), O_{2}$ depletion to preserve flavors from food and beverages (Flavourstar ${ }^{\circledR}$ ) or treatment of wine cork stoppers (Suberzyme ${ }^{\circledR}$ ). Nevertheless, there is room for the application of laccases in other industrial sectors, as demonstrated in many research studies commented below.

<Figure 5 near here>

\section{Pulp and paper industry}

Due to the natural activity of laccases on phenolic lignin, one of the first applications of laccases studied was precisely related to the delignification of wood pulp in the pulp and paper industry (Bourbonnais and Paice, 1992). Laccase-mediator systems can be applied for pulp bleaching and delignification to remove the residual lignin remaining in the paper pulp after cooking. The integration of a laccase-based enzymatic stage in the totally chlorine-free (TCF) or elemental chlorine-free (ECF) bleaching sequences can improve the brightness of the pulps, reduce the use of chlorine-based harsh chemicals in ECF bleaching and, simultaneously, enhance pulp strength properties while reducing the energy consumption during refining of the pulp (García et al., 2003; Camarero et al., 2004; Ibarra et al., 2006). Other applications of laccases related with the paper industry are: i) fiber functionalization through oxidative coupling of low molecular weight compounds (such as phenols) to the paper 
surface, which enhances paper's strength and resistance to water absorption or adds new properties such as antioxidant activity; ii) removal of lipophilic extractives deposited in the bleached pulps ("pitch control"); iii) deinking of secondary fibers; or iv) enzymatic treatment of the effluents from paper mills (Gutiérrez et al., 2007; Widsten and Kandelbauer, 2008; Madhavi and Lele, 2009; Garcia-Ubasart et al., 2011; Fillat et al., 2012; Cusola et al., 2015). Recent functionalization examples by LMS include the grafting of carboxymethyl cellulose and chitosan on kraft pulp fibers to obtain high-resistance papers (Ballinas-Casarrubias et al., 2017) or functionalization of bacterial cellulose to produce paper-silver nanoparticles composites with antimicrobial activities (Morena et al., 2019).

\section{Textile industry}

Laccases can improve the dyeing efficiency and reduce the cost of the dyeing process by in situ oxidation of inexpensive precursors after their adsorption by the fabric, aid textile bleaching by avoiding back staining by degrading the released dyestuff after dyeing, or by bleaching the textile fibers from natural dyes or impurities (Vasil'eva et al., 2008). Some of the first developed commercial laccase formulations are used for denim fabric finishing (fading of indigo-dyed denim) to give the characteristic grey cast (Galante and Formantici, 2003; Pezzella et al., 2015). Laccases have also been used for functional modification of molecules on textile fabrics such as cotton or wool, improving properties as water repellence or resistance (Lantto et al., 2004; Guimarães et al., 2011; Pezzella et al., 2015). In situ polymerization of catechol and $p$ phenylenediamine catalyzed by laccase on different fabrics can yield colored lowconductive fabrics with good fastness behavior after washing (Su et al., 2019a). Moreover, this polymerization reaction has been used for coating wood, cotton and polyethylene terephthalate fabrics to provide antimicrobial properties against grampositive and gram-negative bacteria. These enzyme-treated textile fabrics are of special interest in hospitals to reduce the spread of nosocomial diseases ( $\mathrm{Su}$ et al., 2019b).

\section{Waste treatment}

More demanding environmental regulations have pushed laccases to new application opportunities in waste treatment and disposal (Pezzella et al., 2015). Laccase can transform toxic recalcitrant compounds into less toxic and more degradable

derivatives by direct dechlorinating, cleavage of aromatic rings or oxidative transformation of heterocycles and polycyclic aromatic hydrocarbons in hydroxylated intermediates (Schultz et al., 2001; Cañas et al., 2007; Teng et al., 2019). Wastewaters from the food, textile, dye or printing industries enriched in phenols and aromatic amines can be detoxified with laccases (Lante et al., 2000; Madhavi and Lele, 2009). 
For example, a mix of fungal enzymes containing laccases applied to winery-derived biomass (in combination with a sonication pretreatment) shortened the degradation time required with fungal degradation and produced commercially useful compounds such as gallic acid, lactic acid and glycolic acid (Karpe et al., 2017). The removal of emergent organic pollutants catalyzed by laccase has also been described. For instance, deamination and demethylation of tetracycline and oxytetracycline antibiotics was attained by a fungal laccase (Tian et al., 2020).

Synthetic organic dyes are very stable to temperature, light and microbial attack, making them difficult to degrade. The world total dye production per year is around 800,000 tons of which at least $10 \%$ is released to the environment through wastewaters, where they are a source of eutrophication and can form toxic byproducts through oxidation, hydrolysis or other chemical reactions (Konstantinou and Albanis, 2004). Traditional methods for color removal from these wastewaters, such as filtration, adsorption or coagulation-flocculation, are expensive and have operational problems. Laccases can catalyze the decolorization of a wide range of synthetic organic dyes alone or in the presence of redox mediator compounds (Claus et al., 2002; Gubitz et al., 2002; Camarero et al., 2005). The decolorization is most frequently linked to detoxification. Detoxification of phenolic azo dyes by laccase was proved by the asymmetrical breakdown of the azo linkage releasing molecular nitrogen, avoiding aromatic amine formation (Chivukula and Renganathan, 1995). Other example of azo dye degradation is the use of a laccase from $T$. versicolor for the degradation of orange 2 and acid orange 6 which degradation products were nontoxic (Legerská et al., 2018).

A more detailed description of the use of laccases for waste treatment can be found in Chapter 30047: Michalska et al, Treatment of (Industrial) Wastewaters and Liquid Waste.

\section{Food and beverages}

One relevant example of laccase's application in food and beverage processing is found in the wine industry, to substitute the use of $\mathrm{SO}_{2}$ for the removal of phenolic compounds involved in the maderization of wine, a process that causes turbidity, color intensification, and aroma and flavor alterations. The polyphenols are oxidized by the enzyme, polymerized and removed by clarification. Similar uses have been proposed for the treatment of fruit juices and beer. "Flavourstar" commercial laccase manufactured by Novozymes A/S is used to remove oxygen from finished beer in order to avoid its reaction with proteins or fatty acids, which prevents the formation of off-flavor compounds (Osma et al., 2010). A process that uses laccase as dough additive in baking has also been patented. This process increases the volume and softness of the baked product and at the same time increases strength, stability and 
reduces the stickiness of the dough, thereby improving its machinability. It has been suggested that this effect is produced by the oxidizing effect of the laccase in the dough components improving the strength of the dough gluten structures (Minussi et al., 2002; Pezzella et al., 2015).

\section{Biosensors}

Some optical and thermal biosensors have been reported using laccases, although electrochemical biosensors where laccase is covalently immobilized in carbon-based electrodes, to allow a direct electron transfer, has been widely demonstrated for detection of phenols with low detection limit and high sensitivity (Li et al., 2012; Rodríguez-Delgado et al., 2015). The performance of the biosensor clearly depends on the enzyme immobilization strategy (Casero et al., 2013). A recent study combined botryosphaeran fungal biopolymer with multi-walled carbon nanotubes to immobilize laccase in the electrode, obtaining a novel biosensor for the determination of dopamine and spironolactone with good selectivity (Coelho et al., 2019). As an example of how far the application of laccases in biosensors can go, a textile biosensor was constructed by functionalizing cotton yarn with a semiconducting polymer on which laccase was absorbed. It was demonstrated to monitor human health biomarkers (e.g. Tyr) in a non-invasive way, finding potential application in sport, healthcare and working safety (Battista et al., 2017). Another example is the design of a $\mathrm{pH}$ responsive color-changing wool with conductive features through laccasecatalyzed polymerization of diaminobenzenesulfonic acid (Zhang et al., 2018). In the last years, intensive research has been done on the application of laccases in enzymatic biofuel cells through their immobilization in nanocarbon cathodes modified with metal nanoparticles. This technology, with applications in biosensing, bioreactors or bioenergy conversion (Sekretaryova et al., 2016; Zhang et al., 2017; Rodríguez-Padrón et al., 2018), offers higher redox potentials than commercial fuel cells, but it requires more development studies to be commercialized (Ghosh et al., 2019).

\section{Laccases in organic synthesis}

The synthesis of chemical organic compounds catalyzed by laccase (with or without mediators) has attracted the attention of intensive research in the last two decades to provide a more efficient, cleaner and sustainable alternative to the use of expensive catalysts or toxic reagents.

Laccases can catalyze the synthesis of colorful organic compounds that can be used as dyes trough the oxidation of various phenolic and aromatic precursors. Catechol or indole derivatives (Ganachaud et al., 2008; Kim et al., 2011), phenoxazine-derived dyes such as cinnabarinic acid (Eggert et al., 1995; Bruyneel et al., 2008), and several 
azo dyes have been obtained with laccase as biocatalyst (Polak and Jarosz-Wilkolazka, 2012). The latter are the most used dyes in paper printing and textile dyeing, where they account for around $50 \%$ of the world total dye production due to their color variety (Konstantinou and Albanis, 2004). Some examples of azo dye synthesis by laccase include an azo dye with two anthraquinoinic sulfonated chromophores obtained with immobilized Perenniporia ochroleuca MUCL 41114 laccase (Enaud et al., 2010), or the homocoupling reaction of 4-methylamino benzoic acid mediated by laccase (Martorana et al., 2011). The coupling of phenylenediamine and $\alpha$-naphtol catalyzed by $P$. ostreatus POXA1b laccase renders SIC-RED dye, while the coupling of resorcinol and 2,5-diaminobenzenesulfonic acid renders other colored compounds (Pezzella et al., 2016; Giacobelli et al., 2018). The use of 1-naphtol and 1-naphthol-8amino-3,6-disulfonic acid as precursors catalyzed by a fungal laccase engineered in our lab also rendered a new acidic dye (de Salas et al., 2019a).

Laccases also catalyze the synthesis of pharmaceutical compounds of high value. Some examples are the enzymatic oxidation of 4-methyl-3-hydroxyanthranilic acid to obtain actinocin, a proven antitumoral compound (Osiadacz et al., 1999; Burton, 2005), or the synthesis of the powerful antitumoral drug vinblastine by oxidative coupling of katarantine and vindoline (Sagui et al., 2009). These enzymes have been used to conjugate catechins and dextran to obtain drugs with anticancer activities, or to obtain new derivatives from resveratrol and the hormone $\beta$-estradiol (Nicotra et al., 2004a, 2004b; Vittorio et al., 2016). The regioselectivity of some LMS in oxidation reactions save time and money compared with chemical organic synthesis. Fungal laccases and TEMPO as mediator can selectively oxidize the primary hydroxyl group in monosaccharides and disaccharides under mild conditions for their application in different technical areas (Marzorati et al., 2005). A laccase from Trametes pubescens and TEMPO were used for the oxidation of the primary hydroxyl group of natural glycosides amygdalin or colchicoside to the corresponding carbonyl groups (Baratto et al., 2006). Laccase-TEMPO can also selectively oxidize glycerol to generate glyceraldehyde and glyceric acid (Liebminger et al., 2009), or enhace the antioxidant activity of propolis, attributed to the formation of hydroquine, catechol and phloroglucinol (Botta et al., 2017). More recently, it has been discovered that laccases are capable of selective phenol coupling, as a tailoring step of polyketide synthesis, in the abscense of auxiliary proteins. Polyketides are a structurally and functioanlly diverse class of bioactive natural compounds proven to be a rich source of pharmaceutical and agrochemical lead compounds (Fürtges et al., 2019).

Amination reactions catalyzed by laccase are of interest due to the antibacterial, antifungal, antiallergenic, anti-inflammatory and anticonvulsant activities of aniline derivatives (Niedermeyer et al., 2005). For example, reaction of anilines with 2,5dihydroxybenzoic acid derivatives catalyzed by laccase renders $\mathrm{N}$-analogous of 
corollosporines with important anti-microbial activity (Mikolasch et al., 2008). Other examples are the synthesis of 5-alkylaminobenzoquinone and 2,5-bis(alkylamino)1,4-benzoquinone by oxidative coupling of 2-methoxy-3-methylhydroquinone and primary amines, such as octylamine, cyclooctylamine, and geranylamine (Herter et al., 2011); the dimerization of salicylic esters or bisphenol A (Ciecholewski et al., 2005); the stereoselective amination of racemic sec-alcohols by laccase-TEMPO (MartínezMontero et al., 2017); and the synthesis of triaminated cyclohexa-2,4-dienones using catechol and primary amines as precursors (Wellington et al., 2018). Laccases also catalyze the synthesis of cyclic products using 2,5-dihydroxybenzoic acid derivatives, and aromatic and heteroaromatic amines as precursors through oxidative $\mathrm{C}-\mathrm{N}$ bond formation followed by cyclization (Hahn et al., 2010). Another cyclization reaction catalyzed by laccases is the bioconversion of 2',3,4-trihydroxychalcone to $3^{\prime}, 4^{\prime}$ dihydroxy-aurone. Aurones are plant secondary metabolites with significant biological activity including anti-cancer, anti-parasitic and enzyme-inhibitory activity (Zerva et al., 2019).

\section{- Oxidative coupling and polymerization reactions catalyzed by laccase}

The oxidative coupling of phenols or aromatic amines is one of the most useful abilities of laccases that have been learned from nature, and which are widely exploited in organic synthesis reactions. Lignification of the plant cell walls consists of the oxidative $p$ - and $o$-coupling of phenolic precursors, the cinnamyl alcohols, catalyzed by plant laccases and peroxidases. The electronic delocalization enables the radicals to couple at different sites and yield diverse polymeric products (type of lignins) depending on the abundance of precursors available in the plant or tissue, and the linkages formed (Boerjan et al., 2003). Accordingly, two different dimeric products (with $\mathrm{C}-\mathrm{O}$ or $\mathrm{C}-\mathrm{C}$ bonds) are obtained from in vitro oxidation of ferulic acid catalyzed by laccase, while in vitro oxidation of sinapic acid leads to a single C-C bonded dimer (Tranchimand et al., 2006; Mogharabi and Faramarzi, 2014). The laccase-ABTS system has been used for the catalysis of the oxidative coupling of heterocyclic thiols, rendering their corresponding disulfides, which have numerous applications such as drug delivery systems, vulcanizing agents or as intermediates for the synthesis of sulfinyl and sulfenyl compounds (Abdel-Mohsen et al., 2013).

While the enzymatic polymerization of syringic acid or DMP is regioselective, yielding chains of poly-phenylene oxide units (Ikeda et al., 1996b, 1996a), other oxidative coupling reactions can lead to non-controllable polymer structures with undesirable characteristics. Different strategies have been developed for gaining control of the process and obtaining the desired polymer structure. The presence of organic cosolvents, such as 1,4-dioxane or methanol, increases the solubility of the aromatic 
substrates leading in some cases to an important control over the polydispersity and polymer size (Hollmann and Arends, 2012). In addition to classical organic solvents, ionic liquids have been use as co-solvents for polymerization of phenols (Sgalla et al., 2007; Eker et al., 2009; Khlupova et al., 2016). These chemicals can increase substrate solubility or act as enzyme immobilization matrix, enabling enzyme recycling during the reaction. It has also been observed that ionic liquids stabilize the enzyme in the presence of anionic surfactants required for example for the synthesis of polyaniline, thus increasing polymer yields (Zhang et al., 2014). Regioselectivity is crucial for most polymerization reactions and it can be achieved by substrate engineering. For example, linear conductive polyaniline can be obtained without templates by blocking the $o$-position of aniline. However, this strategy yields a less conductive and electroactive polymer than the standard chemical synthesis of polyaniline (Kim et al., 2007). Some compounds can act as scaffold (templates) during the polymerization reaction to avoid branch formation. These templates are molecules with generally long chain structures that direct the proper alignment of the monomers. In some cases, they are negatively charged, what serves as counter ion (dopant) for the synthesized polymer (Hollmann and Arends, 2012). While templates are often used to achieve polymerization of phenolic precursors, polyaniline synthesis is one of the most significant examples of the use of templates to aid the synthesis of a linear polymer (Kim et al., 2005).

\section{- Synthesis of polyaniline catalyzed by laccase}

Chemical synthesis of conductive polyaniline is relatively cheap due to the low cost of aniline and the high product yields. However, this synthesis is far from environmentally friendly due to the elevated quantities of toxic oxidants needed and the very acidic $\mathrm{pH}$ of the reaction, releasing large quantities of pollutants (Shumakovich et al., 2011). Even more, the polyaniline (PANI) obtained from the chemical polymerization of aniline is soluble only in some organic solvents, making the processability of the product difficult and, hence, increasing the cost of its application (Huang and Kaner, 2006).

On the other hand, the enzymatic polymerization of aniline to produce conductive PANI is environmentally friendly, avoiding the use of chemical oxidizers and allowing to increase the $\mathrm{pH}$ of the reaction up to 3.5 (pH must be below the pKa of aniline -4.6 at $25 \mathrm{C}^{\circ}$ - to have a prevalence of anilinium cations in the reaction). Higher $\mathrm{pH}$ values implicate the prevalence of neutral aniline that yields PANI oligomers with low or none electroconductive capabilities (Sapurina and Stejskal, 2008). Also as aforementioned, only a linear polyaniline can display conductive capabilities. To obtain head to tail polymers and to avoid parasitic branch formation, a co-solvent or template must be present during the reaction (Ćirić-Marjanović et al., 2017). Still 
some template-free synthesis studies of polyaniline using laccase as biocatalyst have been reported. Conductive cotton and bacterial cellulose have been obtained in a free template reaction by in situ polymerization of aniline by laccase using HBT as mediator in an ultrasonic bath (Su et al., 2018; Shim et al., 2019). However, most often the template-free polymers are less defined and with an unclear protonation or oxidation states (Ćirić-Marjanović et al., 2017).

Polyelectrolytes like anionic surfactants, poly(vinylphosphonic acid), sulfonated polystyrene or even DNA are commonly used as templates for the synthesis of electroactive PANI (Liu et al., 1999; Nagarajan et al., 2000, 2001; Karamyshev et al., 2003). Among templates, anionic surfactants are preferred due their commercial availability and capability to maintain the water solubility of PANI, thus increasing its processability. These templates aggregate to form micelles over a critical micellar concentration, providing a suitable local environment for aniline $p$-coupling (Hino et al., 2006). The polymerization process of aniline associated to this micellar structure yields water soluble PANI, that can be precipitated by adding an organic solvent, like ethanol or acetone, to disaggregate the anionic surfactant micelles (Streltsov et al., 2008). Different macromolecular structures can be obtained by changing the anionic surfactant during the enzymatic synthesis of PANI. Anionic surfactants usually inhibit enzyme activity by protein denaturation, although the presence of aniline protects the enzyme from the action of the surfactant (Otzen, 2011). The use of different anionic surfactants and different concentrations yields polyaniline with different spectrometric and macromolecular structures. Polyaniline with excellent electrochemical and electro-conductive properties was synthesized by using a fungal laccase variant engineered in our lab in the presence of sodium dodecylbenzenesulfonate (SDBS) as doping template (Fig. 6). The PANI obtained is displayed in nanofibers, which provides additional advantages over other macromolecular assemblies like a porous structure and a large surface-to-volume ratio, which are optimal properties for biosensor development (De Salas et al., 2016). More recently, polyaniline's production yield has been enhanced up to $87 \%(\mathrm{w} / \mathrm{w}$, referred to aniline precursor) by the additional engineering of the laccase through directed evolution and semi-rational design (de Salas et al., 2019a).

<Figure 6 near here>

\section{Conclusions}

The high redox potential of fungal laccases boosts their capabilities to oxidize diverse aromatic compounds, which together with the use of $\mathrm{O}_{2}$ from the air as sole catalytic requirement, make these enzymes biocatalysts of choice for many industrial sectors. Some of the first applications of fungal laccases were related to the pulp and paper industry, taking advantage of their intrinsic high activity on lignin phenols associated 
with their natural function in plants and fungi. Their use as biocatalyst in textile, food and beverage industries and waste treatment have also been historically targeted in many research studies. In the last two decades, new research studies emerged to open the range of laccase's applications to biosensor design or to catalyze organic synthesis reactions, with promising results. Many of the examples described have been relegated over the years to the laboratory environment. The difficult overexpression of fungal laccases and need to adjust their catalytic activity and stability to operational conditions are main hurdles for the industrial application of these enzymes. However, new and more restrictive environmental regulations could be the catalyzer for the implementation of some of these new enzymatic processes to an industrial scale.

\section{References}

Abdel-Mohsen, H.T., Sudheendran, K., Conrad, J., Beifuss, U., 2013. Synthesis of disulfides by laccase-catalyzed oxidative coupling of heterocyclic thiols. Green Chem. 15, 1490-1495. https://doi.org/10.1039/c3gc40106e

Abianova, A.R., Chulkin, A.M., Vavilova, E.A., Fedorova, T. V, Loginov, D.S., Koroleva, O. V, Benevolenskiŭ, S. V, 2010. A heterologous production of the Trametes hirsuta laccase in the fungus Penicillium canescens. Prikl. Biokhim. Mikrobiol. 46, 342-347.

Alessandra, P., Cinzia, P., Paola, G., Vincenza, F., Sannia, G., 2010. Heterologous laccase production and its role in industrial applications. Bioeng. Bugs 1, 252-262. https://doi.org/10.4161/bbug.1.4.11438

Alves, A.M.C.R., Record, E., Lomascolo, A., Scholtmeijer, K., Asther, M., Wessels, J.G.H., Wo, H.A.B., 2004. Highly efficient production of laccase by the basidiomycete Pycnoporus cinnabarinus. Appl. Environ. Microbiol. 70, 6379-6384. https://doi.org/10.1128/AEM.70.11.6379

Augustine, A.J., Kragh, M.E., Sarangi, R., Fujii, S., Liboiron, B.D., Stoj, C.S., Kosman, D.J., Hodgson, K.O., Hedman, B., Solomon, E.I., 2008. Spectroscopic studies of perturbed T1 $\mathrm{Cu}$ sites in the multicopper oxidases Saccharomyces cerevisiae Fet3p and Rhus vernicifera laccase: Allosteric coupling between the T1 and trinuclear Cu sites. Biochemistry 47, 2036-2045. https://doi.org/10.1021/bi7020052

Babot, E.D., Rico, A., Rencoret, J., Kalum, L., Lund, H., Romero, J., del Río, J.C., Martínez, Á.T., Gutiérrez, A., 2011. Towards industrially-feasible delignification and pitch removal by treating paper pulp with Myceliophthora thermophila laccase and a phenolic mediator. Bioresour. Technol. 102, 6717-6722. https://doi.org/10.1016/j.biortech.2011.03.100

Baiocco, P., Barreca, A.M., Fabbrini, M., Galli, C., Gentili, P., 2003. Promoting laccase activity towards non-phenolic substrates: A mechanistic investigation with some laccase-mediator systems. Org. Biomol. Chem. 1, 191-197. https://doi.org/10.1039/b208951c

Ballinas-Casarrubias, L., Villanueva-Solís, L., Espinoza-Hicks, C., Camacho-Dávila, A., Castillo, H.A.P., Pérez, S.B., Villa, E.D., De Dios Hernández, M., González-Sánchez, G., 2017. Effect of laccase-mediated biopolymer grafting on kraft pulp fibers for enhancing paper's mechanical properties. Polymers (Basel). 9. https://doi.org/10.3390/polym9110570

Baratto, L., Candido, A., Marzorati, M., Sagui, F., Riva, S., Danieli, B., 2006. Laccase-mediated oxidation of natural glycosides. J. Mol. Catal. B Enzym. 39, 3-8. https://doi.org/10.1016/j.molcatb.2006.01.011

Battista, E., Lettera, V., Villani, M., Calestani, D., Gentile, F., Netti, P.A., Iannotta, S., Zappettini, A., Coppedè, N., 2017. Enzymatic sensing with laccase-functionalized textile organic biosensors. Org. Electron. 40, 51-57. https://doi.org/10.1016/j.orgel.2016.10.037 
Benzina, O., Frikha, F., Zouari-Mechichi, H., Woodward, S., Belbahri, L., Mnif, E., Mechichi, T., 2012. Enhanced decolourization of the azo dye Sirius rose BB by laccase-HBT system. 3 Biotech 2, 149-157. https://doi.org/10.1007/s13205-011-0041-5

Boerjan, W., Ralph, J., Baucher, M., 2003. Lignin biosynthesis. Annu. Rev. Plant Biol. 54, 519-546. https://doi.org/10.1146/annurev.arplant.54.031902.134938

Botta, L., Brunori, F., Tulimieri, A., Piccinino, D., Meschini, R., Saladino, R., 2017. Laccase-mediated enhancement of the antioxidant activity of propolis and poplar bud exudates. ACS Omega 2, 2515-2523. https://doi.org/10.1021/acsomega.7b00294

Bourbonnais, R., Paice, M.G., 1992. Demethylation and delignification of kraft pulp by Trametes versicolor laccase in the presence of 2,2'-azinobis-(3-ethylbenzthiazoline-6-sulphonate). Appl. Microbiol. Biotechnol. 36, 823827. https://doi.org/10.1007/BF00172202

Bourbonnais, R., Paice, M.G., 1990. Oxidation of non-phenolic substrates. An expanded role for laccase in lignin biodegradation. FEBS Lett. 267, 99-102. https://doi.org/10.1016/0014-5793(90)80298-W

Bruyneel, F., Enaud, E., Billottet, L., Vanhulle, S., Marchand-Brynaert, J., 2008. Regioselective synthesis of 3hydroxyorthanilic acid and its biotransformation into a novel phenoxazinone dye by use of laccase. European J. Org. Chem. 72-79. https://doi.org/10.1002/ejoc.200700865

Bulter, T., Alcalde, M., Sieber, V., Schlachtbauer, C., Arnold, F.H., 2003. Functional expression of a fungal laccase in Saccharomyces cerevisiae by directed evolution. Microbiology 69, 987-995. https://doi.org/10.1128/AEM.69.2.987

Burda, P., Aebi, M., 1999. The dolichol pathway of N-linked glycosylation. Biochim. Biophys. Acta - Gen. Subj. 1426, 239-257. https://doi.org/10.1016/S0304-4165(98)00127-5

Burton, S., 2005. Laccases and phenol oxidases in organic synthesis - a review. Curr. Org. Chem. 7, 1317-1331. https://doi.org/10.2174/1385272033486477

Call, H.P., Mücke, I., 1997. History, overview and applications of mediated lignolytic systems, especially laccasemediator-systems (Lignozym $®$-process). J. Biotechnol. 53, 163-202. https://doi.org/10.1016/S01681656(97)01683-0

Camarero, S., Cañas, A.I., Nousiainen, P., Record, E., Lomascolo, A., Martínez, M.J., Martínez, Á.T., 2008. pHydroxycinnamic acids as natural mediators for laccase oxidation of recalcitrant compounds. Environ. Sci. Technol. 42, 6703-6709. https://doi.org/10.1021/es8008979

Camarero, S., García, O., Vidal, T., Colom, J., Del Río, J.C., Gutiérrez, A., Gras, J.M., Monje, R., Martínez, M.J., Martínez, Á.T., 2004. Efficient bleaching of non-wood high-quality paper pulp using laccase-mediator system. Enzyme Microb. Technol. 35, 113-120. https://doi.org/10.1016/j.enzmictec.2003.10.019

Camarero, S., Ibarra, D., Martínez, Á.T., Romero, J., Gutiérrez, A., del Río, J.C., 2007. Paper pulp delignification using laccase and natural mediators. Enzyme Microb. Technol. 40, 1264-1271. https://doi.org/10.1016/j.enzmictec.2006.09.016

Camarero, S., Ibarra, D., Martınez, M.J., Martınez, A.T., 2005. Lignin-derived compounds as efficient laccase mediators of different types of recalcitrant dyes. Appl. Environ. Microbiol. 71, 1775-1784. https://doi.org/10.1128/AEM.71.4.1775

Camarero, S., Pardo, I., Cañas, a. I., Molina, P., Record, E., Martínez, a. T., Martínez, M.J., Alcalde, M., 2012. Engineering platforms for directed evolution of laccase from Pycnoporus cinnabarinus. Appl. Environ. Microbiol. 78, 1370-1384. https://doi.org/10.1128/AEM.07530-11

Cañas, A.I., Alcalde, M., Plou, F., Martínez, M.J., Martínez, Á.T., Camarero, S., 2007. Transformation of polycyclic aromatic hydrocarbons by laccase is strongly enhanced by phenolic compounds present in soil. Environ. Sci. Technol. 41, 2964-2971. https://doi.org/10.1021/es062328j

Cañas, A.I., Camarero, S., 2010. Laccases and their natural mediators: Biotechnological tools for sustainable ecofriendly processes. Biotechnol. Adv. 28, 694-705. https://doi.org/10.1016/j.biotechadv.2010.05.002 
Casado López, S., Sietiö, O.-M., Hildén, K., de Vries, R.P., Mäkelä, M.R., 2016. Homologous and heterologous expression of basidiomycete genes related to plant biomass degradation, in: Schmoll, M., Dattenböck, C. (Eds.), Gene Expression Systems in Fungi: Advancements and Applications. Springer International Publishing, Cham, pp. 119-160. https://doi.org/10.1007/978-3-319-27951-0_5

Casero, E., Petit-Domínguez, M.D., Vázquez, L., Ramírez-Asperilla, I., Parra-Alfambra, A.M., Pariente, F., Lorenzo, E., 2013. Laccase biosensors based on different enzyme immobilization strategies for phenolic compounds determination. Talanta 115, 401-408. https://doi.org/10.1016/j.talanta.2013.05.045

Cereghino, J., 2002. Heterologous protein expression in the methylotrophic yeast Pichia pastoris. FEMS Microbiol. Rev. 24, 45-66. https://doi.org/10.1016/s0168-6445(99)00029-7

Chivukula, M., Renganathan, V., 1995. Phenolic azo dye oxidation by laccase from Pyricularia oryzae. Appl. Environ. Microbiol. 61, 4374-4377.

Ciecholewski, S., Hammer, E., Manda, K., Bose, G., Nguyen, V.T.H., Langer, P., Schauer, F., 2005. Laccase-catalyzed carbon-carbon bond formation: Oxidative dimerization of salicylic esters by air in aqueous solution. Tetrahedron 61, 4615-4619. https://doi.org/10.1016/j.tet.2005.03.007

Ćirić-Marjanović, G., Milojević-Rakić, M., Janošević-Ležaić, A., Luginbühl, S., Walde, P., 2017. Enzymatic oligomerization and polymerization of arylamines: State of the art and perspectives. Chem. Pap. 71, 199-242. https://doi.org/10.1007/s11696-016-0094-3

Claus, H., 2004. Laccases: Structure, reactions, distribution. Micron 35, 93-96. https://doi.org/10.1016/j.micron.2003.10.029

Claus, H., Faber, G., König, H., 2002. Redox-mediated decolorization of synthetic dyes by fungal laccases. Appl. Microbiol. Biotechnol. 59, 672-678. https://doi.org/10.1007/s00253-002-1047-z

Coelho, J.H., Eisele, A.P.P., Valezi, C.F., Mattos, G.J., Schirmann, J.G., Dekker, R.F.H., Barbosa-Dekker, A.M., Sartori, E.R., 2019. Exploring the exocellular fungal biopolymer botryosphaeran for laccase-biosensor architecture and application to determine dopamine and spironolactone. Talanta 204, 475-483. https://doi.org/10.1016/j.talanta.2019.06.033

Couto, S.R., Toca-Herrera, J.L., 2007. Laccase production at reactor scale by filamentous fungi. Biotechnol. Adv. 25, 558-569. https://doi.org/10.1016/j.biotechadv.2007.07.002

Cusola, O., Valls, C., Vidal, T., Roncero, M.B., 2015. Conferring antioxidant capacity to cellulose based materials by using enzymatically-modified products. Cellulose 22, 2375-2390. https://doi.org/10.1007/s10570-0150668-1

de Salas, F., Aza, P., Gilabert, J.F., Santiago, G., Kilic, S., Sener, M.E., Vind, J., Guallar, V., Martínez, A.T., Camarero, S., 2019a. Engineering of a fungal laccase to develop a robust, versatile and highly-expressed biocatalyst for sustainable chemistry. Green Chem. 5374-5385. https://doi.org/10.1039/c9gc02475a

de Salas, F., Cañadas, R., Santiago, G., Virseda-Jerez, A., Vind, J., Gentili, P., Martínez, A.T., Guallar, V., Muñoz, I.G., Camarero, S., 2019b. Structural and biochemical insights into an engineered high-redox potential laccase overproduced in Aspergillus. Int. J. Biol. Macromol. https://doi.org/10.1016/j.ijbiomac.2019.09.052

De Salas, F., Pardo, I., Salavagione, H.J., Aza, P., Amougi, E., Vind, J., Martínez, A.T., Camarero, S., 2016. Advanced synthesis of conductive polyaniline using laccase as biocatalyst. PLoS One 11, 1-18. https://doi.org/10.1371/journal.pone.0164958

Durão, P., Bento, I., Fernandes, A.T., Melo, E.P., Lindley, P.F., Martins, L.O., 2006. Perturbations of the T1 copper site in the CotA laccase from Bacillus subtilis: Structural, biochemical, enzymatic and stability studies. J. Biol. Inorg. Chem. 11, 514-526. https://doi.org/10.1007/s00775-006-0102-0

Eggert, C., Temp, U., Dean, J.F.D., Eriksson, K.E.L., 1995. Laccase-mediated formation of the phenoxazinone derivative, cinnabarinic acid. FEBS Lett. 376, 202-206. https://doi.org/10.1016/0014-5793(95)01274-9

Eggert, C., Temp, U., Eriksson, K.E.L., 1996. The ligninolytic system of the white rot fungus Pycnoporus cinnabarinus: Purification and characterization of the laccase. Appl. Environ. Microbiol. 62, 1151-1158. 
Eker, B., Zagorevski, D., Zhu, G., Linhardt, R.J., Dordick, J.S., 2009. Enzymatic polymerization of phenols in roomtemperature ionic liquids. J. Mol. Catal. B Enzym. 59, 177-184. https://doi.org/10.1016/j.molcatb.2009.02.018

Enaud, E., Trovaslet, M., Bruyneel, F.F., Billottet, L., Karaaslan, R., Sener, M.E., Coppens, P., Casas, A., Jaeger, I.J., Hafner, C., Onderwater, R.C.A.A., Corbisier, A.M., Marchand-Brynaert, J., Vanhulle, S., 2010. A novel azoanthraquinone dye made through innovative enzymatic process. Dye. Pigment. 85, 99-108. https://doi.org/10.1016/j.dyepig.2009.10.010

Fillat, U., Prieto, A., Camarero, S., Martínez, Á.T., Martínez, M.J., 2012. Biodeinking of flexographic inks by fungal laccases using synthetic and natural mediators. Biochem. Eng. J. 67, 97-103. https://doi.org/10.1016/j.bej.2012.05.010

Fürtges, L., Obermaier, S., Thiele, W., Foegen, S., Müller, M., 2019. Diversity in fungal intermolecular phenol coupling of polyketides: regioselective laccase-based systems. ChemBioChem 20, 1928-1932. https://doi.org/10.1002/cbic.201900041

Galante, Y.M., Formantici, C., 2003. Enzyme applications in detergency and in manufacturing industries. Curr. Org. Chem. 7, 1399-1422. https://doi.org/10.2174/1385272033486468Galli, C., Gentili, P., 2004. Chemical messengers: Mediated oxidations with the enzyme laccase. J. Phys. Org. Chem. 17, 973-977. https://doi.org/10.1002/poc.812

Galli, C., Madzak, C., Vadalà, R., Jolivalt, C., Gentili, P., 2013. Concerted electron/proton transfer mechanism in the oxidation of phenols by laccase. ChemBioChem 14, 2500-2505. https://doi.org/10.1002/cbic.201300531

Ganachaud, C., Garfagnoli, V., Tron, T., Iacazio, G., 2008. Trimerisation of indole through laccase catalysis. Tetrahedron Lett. 49, 2476-2478. https://doi.org/10.1016/j.tetlet.2008.02.021

Garcia-Ubasart, J., Esteban, A., Vila, C., Roncero, M.B., Colom, J.F., Vidal, T., 2011. Enzymatic treatments of pulp using laccase and hydrophobic compounds. Bioresour. Technol. 102, 2799-2803. https://doi.org/10.1016/j.biortech.2010.10.020

García, O., Camarero, S., Colom, J.F., Martínez, Á.T., Martínez, M.J., Monje, R., Vidal, T., 2003. Optimization of a laccase-mediator stage for TCF bleaching of flax pulp. Holzforschung 57, 513-519. https://doi.org/10.1515/HF.2003.076

Ghosh, B., Saha, R., Bhattacharya, D., Mukhopadhyay, M., 2019. Laccase and its source of sustainability in an enzymatic biofuel cell. Bioresour. Technol. Reports 6, 268-278. https://doi.org/10.1016/j.biteb.2019.03.013

Giacobelli, V.G., Pezzella, C., Sannia, G., Olivieri, G., Fontanarosa, C., Amoresano, A., Piscitelli, A., 2018. Laccase-based synthesis of SIC-RED: A new dyeing product for protein gel staining. Biocatal. Agric. Biotechnol. 15, 270-276. https://doi.org/10.1016/j.bcab.2018.06.023

Gianfreda, L., Xu, F., Bollag, J.-M., 1999. Laccases: A useful group of oxidoreductive enzymes. Bioremediat. J. 3, 1-26. https://doi.org/10.1080/10889869991219163

Gonzalez-Perez, D., Garcia-Ruiz, E., Alcalde, M., 2012. Saccharomyces cerevisiae in directed evolution: An efficient tool to improve enzymes. Bioeng. Bugs 3, 172-177. https://doi.org/10.4161/bbug.19544

Gubitz, G.M., Costa, S., Tzanov, T., Cavaco-Paulo, A., Robra, K.-H., Abadulla, E., 2002. Decolorization and detoxification of textile dyes with a laccase from Trametes hirsuta. Appl. Environ. Microbiol. 66, 3357-3362. https://doi.org/10.1128/aem.66.8.3357-3362.2000

Guimarães, C., Kim, S., Silva, C., Cavaco-Paulo, A., 2011. In situ laccase-assisted overdyeing of denim using flavonoids. Biotechnol. J. 6, 1272-1279. https://doi.org/10.1002/biot.201100201

Gutiérrez, A., Rencoret, J., Ibarra, D., Molina, S., Camarero, S., Romero, J., Del Río, J.C., Martínez, Á.T., 2007. Removal of lipophilic extractives from paper pulp by laccase and lignin-derived phenols as natural mediators. Environ. Sci. Technol. 41, 4124-4129. https://doi.org/10.1021/es062723+

Hahn, V., Davids, T., Lalk, M., Schauer, F., Mikolasch, A., 2010. Enzymatic cyclizations using laccases: Multiple bond formation between dihydroxybenzoic acid derivatives and aromatic amines. Green Chem. 12, 879-887. 
https://doi.org/10.1039/b920081a

Hakulinen, N., Kiiskinen, L.-L., Kruus, K., Saloheimo, M., Paananen, A., Koivula, A., Rouvinen, J., 2002. Crystal structure of a laccase from Melanocarpus albomyces with an intact trinuclear copper site. Nat. Struct. Biol. 9, 601-605. https://doi.org/10.1038/nsb823

Hakulinen, N., Rouvinen, J., 2015. Three-dimensional structures of laccases. Cell. Mol. Life Sci. 72, $857-868$. https://doi.org/10.1007/s00018-014-1827-5

Hall, J.F., Kanbi, L.D., Strange, R.W., Hasnain, S.S., 1999. Role of the axial ligand in type 1 Cu centers studied by point mutations of Met148 in rusticyanin. Biochemistry 38, 12675-12680. https://doi.org/10.1021/bi990983g

Hämäläinen, V., Grönroos, T., Suonpää, A., Heikkilä, M.W., Romein, B., Ihalainen, P., Malandra, S., Birikh, K.R., 2018. Enzymatic processes to unlock the lignin value. Front. Bioeng. Biotechnol. 6, 1-10. https://doi.org/10.3389/fbioe.2018.00020

Herscovics, A., 1999. Processing glycosidases of Saccharomyces cerevisiae. Biochim. Biophys. Acta - Gen. Subj. 1426, 275-285. https://doi.org/10.1016/S0304-4165(98)00129-9

Herter, S., Mikolasch, A., Michalik, D., Hammer, E., Schauer, F., Bornscheuer, U., Schmidt, M., 2011. C-N coupling of 3methylcatechol with primary amines using native and recombinant laccases from Trametes versicolor and Pycnoporus cinnabarinus. Tetrahedron 67, 9311-9321. https://doi.org/10.1016/j.tet.2011.09.123

Hildén, K., Mäkelä, M.R., Lundell, T., Kuuskeri, J., Chernykh, A., Golovleva, L., Archer, D.B., Hatakka, A., 2013. Heterologous expression and structural characterization of two low $\mathrm{pH}$ laccases from a biopulping white-rot fungus Physisporinus rivulosus. Appl. Microbiol. Biotechnol. 97, 1589-1599. https://doi.org/10.1007/s00253-012-4011-6

Hino, T., Namiki, T., Kuramoto, N., 2006. Synthesis and characterization of novel conducting composites of polyaniline prepared in the presence of sodium dodecylsulfonate and several water soluble polymers. Synth. Met. 156, 1327-1332. https://doi.org/10.1016/j.synthmet.2006.10.001

Hoegger, P.J., Kilaru, S., James, T.Y., Thacker, J.R., Kües, U., 2006. Phylogenetic comparison and classification of laccase and related multicopper oxidase protein sequences. FEBS J. 273, 2308-2326. https://doi.org/10.1111/j.1742-4658.2006.05247.x

Hollmann, F., Arends, I.W.C.E., 2012. Enzyme initiated radical polymerizations. Polymers (Basel). 4, $759-793$. https://doi.org/10.3390/polym4010759

Hong, F., Meinander, N.Q., Jönsson, L.J., 2002. Fermentation strategies for improved heterologous expression of laccase in Pichia pastoris. Biotechnol. Bioeng. 79, 438-449. https://doi.org/10.1002/bit.10297

Huang, J., Kaner, R.B., 2006. The intrinsic nanofibrillar morphology of polyaniline. Chem. Commun. (Camb). 367-76. https://doi.org/10.1039/b510956f

Ibarra, D., Camarero, S., Romero, J., Martınez, M.J., Martınez, A.T., 2006. Integrating laccase-mediator treatment into an industrial-type sequence for totally chlorine-free bleaching of eucalypt kraft pulp. J. Chem. Technol. Biotechnol. 81, 1159-1165. https://doi.org/10.1002/jctb

Ikeda, R., Sugihara, J., Uyama, H., Kobayashi, S., 1996a. Enzymatic oxidative polymerization of 2,6-dimethylphenol. Macromolecules 29, 8702-8705. https://doi.org/10.1021/ma961055h

Ikeda, R., Uyama, H., Kobayashi, S., 1996b. Novel synthetic pathway to a poly(phenylene oxide). Laccase-catalyzed oxidative polymerization of syringic acid. Macromolecules 29, 3053-3054. https://doi.org/10.1021/ma951810b

Jones, S.M., Solomon, E.I., 2015. Electron transfer and reaction mechanism of laccases. Cell. Mol. Life Sci. 72, 869883. https://doi.org/10.1007/s00018-014-1826-6

Kajita, S., Sugawara, S., Miyazaki, Y., Nakamura, M., Katayama, Y., Shishido, K., Iimura, Y., 2004. Overproduction of recombinant laccase using a homologous expression system in Coriolus versicolor. Appl. Microbiol. Biotechnol. 66, 194-199. https://doi.org/10.1007/s00253-004-1663-x 
Karamyshev, A. V, Shleev, S. V, Koroleva, O. V, Yaropolov, A.I., Sakharov, I.Y., 2003. Laccase-catalyzed synthesis of conducting polyaniline. Enzyme Microb. Technol. 33, 556-564. https://doi.org/10.1016/S01410229(03)00163-7

Karpe, A. V., Dhamale, V. V., Morrison, P.D., Beale, D.J., Harding, I.H., Palombo, E.A., 2017. Winery biomass waste degradation by sequential sonication and mixed fungal enzyme treatments. Fungal Genet. Biol. 102, 22-30. https://doi.org/10.1016/j.fgb.2016.08.008

Khlupova, M.E., Lisitskaya, K. V., Amandusova, A.H., Shumakovich, G.P., Vasil'eva, I.S., Zaitseva, E.A., Morozova, O. V., Yaropolov, A.I., 2016. Dihydroquercetin polymerization using laccase immobilized into an ionic liquid. Appl. Biochem. Microbiol. 52, 452-456. https://doi.org/10.1134/s0003683816040098

Kilaru, S., Hoegger, P.J., Majcherczyk, A., Burns, C., Shishido, K., Bailey, A., Foster, G.D., Kües, U., 2006. Expression of laccase gene lcc1 in Coprinopsis cinerea under control of various basidiomycetous promoters. Appl. Microbiol. Biotechnol. 71, 200-210. https://doi.org/10.1007/s00253-005-0128-1

Kim, S.-C.C., Huh, P., Kumar, J., Kim, B., Lee, J.-O.O., Bruno, F.F., Samuelson, L.A., 2007. Synthesis of polyaniline derivatives via biocatalysis. Green Chem. 9, 44. https://doi.org/10.1039/b606839a

Kim, S., Silva, C., Evtuguin, D. V., Gamelas, J.A.F., Cavaco-Paulo, A., 2011. Polyoxometalate/laccase-mediated oxidative polymerization of catechol for textile dyeing. Appl. Microbiol. Biotechnol. 89, 981-987. https://doi.org/10.1007/s00253-010-2932-5

Kim, Y.-J., Uyama, H., Kobayashi, S., 2005. Enzymatic template polymerization of phenol in the presence of watersoluble polymers in an aqueous medium. Polym. J. 36, 992-998. https://doi.org/10.1295/polymj.36.992

Kittl, R., Gonaus, C., Pillei, C., Haltrich, D., Ludwig, R., 2012. Constitutive expression of Botrytis aclada laccase in Pichia pastoris. Bioengineered 3, 232-235. https://doi.org/10.4161/bbug.20037

Konstantinou, I.K., Albanis, T.A., 2004. TiO2-assisted photocatalytic degradation of azo dyes in aqueous solution: Kinetic and mechanistic investigations: A review. Appl. Catal. B Environ. 49, 1-14. https://doi.org/10.1016/j.apcatb.2003.11.010

Kunamneni, A., Camarero, S., García-Burgos, C., Plou, F.J., Ballesteros, A., Alcalde, M., 2008. Engineering and applications of fungal laccases for organic synthesis. Microb. Cell Fact. 7, 1-17. https://doi.org/10.1186/1475-2859-7-32

Lante, A., Crapisi, A., Krastanov, A., Spettoli, P., 2000. Biodegradation of phenols by laccase immobilised in a membrane reactor. Process Biochem. 36, 51-58. https://doi.org/10.1016/S0032-9592(00)00180-1

Lantto, R., Schönberg, C., Buchert, J., Heine, E., 2004. Effects of laccase-mediator combinations on wool. Text. Res. J. 74, 713-717. https://doi.org/10.1177/004051750407400809

Legerská, B., Chmelová, D., Ondrejovič, M., 2018. Decolourization and detoxification of monoazo dyes by laccase from the white-rot fungus Trametes versicolor. J. Biotechnol. 285, 84-90. https://doi.org/10.1016/j.jbiotec.2018.08.011

Li, Y., Zhang, L., Li, M., Pan, Z., Li, D., 2012. A disposable biosensor based on immobilization of laccase with silica spheres on the MWCNTs-doped screen-printed electrode. Chem. Cent. J. 6, 1. https://doi.org/10.1186/1752153X-6-103

Liebminger, S., Siebenhofer, M., Guebitz, G., 2009. Oxidation of glycerol by 2,2,6,6-tetramethylpiperidine-N-oxyl (TEMPO) in the presence of laccase. Bioresour. Technol. 100, 4541-4545. https://doi.org/10.1016/j.biortech.2009.04.051

Liu, W., Kumar, J., Tripathy, S., Senecal, K.J., Samuelson, L., 1999. Enzymatically synthesized conducting polyaniline. J. Am. Chem. Soc. 121, 71-78. https://doi.org/10.1021/ja982270b

Lomascolo, A., Record, E., Herpoël-Gimbert, I., Delattre, M., Robert, J.L., Georis, J., Dauvrin, T., Sigoillot, J.C., Asther, M., 2003. Overproduction of laccase by a monokaryotic strain of Pycnoporus cinnabarinus using ethanol as inducer. J. Appl. Microbiol. 94, 618-624. https://doi.org/10.1046/j.1365-2672.2003.01879.x 
Lundell, T.K., Mäkelä, M.R., Hildén, K., 2010. Lignin-modifying enzymes in filamentous basidiomycetes - Ecological, functional and phylogenetic review. J. Basic Microbiol. 50, 5-20. https://doi.org/10.1002/jobm.200900338

Ma, S., Liu, N., Jia, H., Dai, D., Zang, J., Cao, Z., Dong, J., 2018. Expression, purification, and characterization of a novel laccase from Setosphaeria turcica in Eschericha coli. J. Basic Microbiol. 58, 68-75. https://doi.org/10.1002/jobm.201700212

Macellaro, G., Baratto, M.C., Piscitelli, A., Pezzella, C., Fabrizi De Biani, F., Palmese, A., Piumi, F., Record, E., Basosi, R., Sannia, G., 2014. Effective mutations in a high redox potential laccase from Pleurotus ostreatus. Appl. Microbiol. Biotechnol. 98, 4949-4961. https://doi.org/10.1007/s00253-013-5491-8

Madhavi, V., Lele, S.S., 2009. Laccase: Properties and applications. BioResources 4, 1694-1717.

Martínez-Montero, L., Gotor, V., Gotor-Fernández, V., Lavandera, I., 2017. Stereoselective amination of racemic secalcohols through sequential application of laccases and transaminases. Green Chem. 19, 474-480. https://doi.org/10.1039/c6gc01981a

Marzorati, M., Danieli, B., Haltrich, D., Riva, S., 2005. Selective laccase-mediated oxidation of sugars derivatives. Green Chem. 7, 310-315. https://doi.org/10.1039/b416668j

Mate, D.M., García-Burgos, C., García-Ruiz, E., Ballesteros, A.O., Camarero, S., Alcalde, M., 2010. Laboratory evolution of high-redox potential laccases. Chem. Biol. 17, 1030-1041. https://doi.org/10.1016/j.chembiol.2010.07.010

Mate, D.M., Gonzalez-Perez, D., Kittl, R., Ludwig, R., Alcalde, M., 2013. Functional expression of a blood tolerant laccase in Pichia pastoris. BMC Biotechnol. 13, 38. https://doi.org/10.1186/1472-6750-13-38

Martorana, A., Bernini, C., Valensin, D., Sinicropi, A., Pogni, R., Basosi, R., Baratto, M.C., 2011. Insights into the homocoupling reaction of 4-methylamino benzoic acid mediated by Trametes versicolor laccase. Mol. Biosyst. 7, 2967-2969. https://doi.org/10.1039/c1mb05301a

Mekmouche, Y., Zhou, S., Cusano, A.M., Record, E., Lomascolo, A., Robert, V., Simaan, A.J., Rousselot-Pailley, P., Ullah, S., Chaspoul, F., Tron, T., 2014. Gram-scale production of a basidiomycetous laccase in Aspergillus niger. J. Biosci. Bioeng. 117, 25-27. https://doi.org/10.1016/j.jbiosc.2013.06.013

Mikolasch, A., Hessel, S., Salazar, M.G., Neumann, H., Manda, K., Gōrdes, D., Schmidt, E., Thurow, K., Hammer, E., Lindequist, U., Beller, M., Schauer, F., 2008. Synthesis of new N-analogous corollosporine derivatives with antibacterial activity by laccase-catalyzed amination. Chem. Pharm. Bull. (Tokyo). 56, 781-6.

Minussi, R.C., Pastore, G.M., Durán, N., 2002. Potential applications of laccase in the food industry. Trends Food Sci. Technol. 13, 205-216. https://doi.org/10.1016/S0924-2244(02)00155-3

Mogharabi, M., Faramarzi, M.A., 2014. Laccase and laccase-mediated systems in the synthesis of organic compounds. Adv. Synth. Catal. 356, 897-927. https://doi.org/10.1002/adsc.201300960

Morena, A.G., Roncero, M.B., Valenzuela, S. V., Valls, C., Vidal, T., Pastor, F.I.J., Diaz, P., Martínez, J., 2019. Laccase/TEMPO-mediated bacterial cellulose functionalization: production of paper-silver nanoparticles composite with antimicrobial activity. Cellulose 5, 8655-8668. https://doi.org/10.1007/s10570-019-026785

Morozova, O. V., Shumakovich, G.P., Gorbacheva, M.A., Shleev, S. V., Yaropolov, A.I., 2007. “Blue” laccases. Biochem. 72, 1136-1150. https://doi.org/10.1134/S0006297907100112

Nagarajan, R., Liu, W., Kumar, J., Tripathy, S.K., Bruno, F.F., Samuelson, L.A., 2001. Manipulating DNA conformation using intertwined conducting polymer chains. Macromolecules 34, 3921-3927. https://doi.org/10.1021/ma0021287

Nagarajan, R., Tripathy, S., Kumar, J., Bruno, F.F., Samuelson, L., 2000. Enzymatically synthesized conducting molecular complex of polyaniline and poly(vinylphosphonic acid). Macromolecules 33, 9542-9547. https://doi.org/10.1021/ma000954+

Nicotra, S., Cramarossa, M.R., Mucci, A., Pagnoni, U.M., Riva, S., Forti, L., 2004a. Biotransformation of resveratrol: 
Synthesis of trans-dehydrodimers catalyzed by laccases from Myceliophtora thermophyla and from Trametes pubescens. Tetrahedron 60, 595-600. https://doi.org/10.1016/j.tet.2003.10.117

Nicotra, S., Intra, A., Ottolina, G., Riva, S., Danieli, B., 2004b. Laccase-mediated oxidation of the steroid hormone $17 \beta$-estradiol in organic solvents. Tetrahedron Asymmetry 15, 2927-2931. https://doi.org/10.1016/j.tetasy.2004.06.034

Niedermeyer, T.H.J., Mikolasch, A., Lalk, M., 2005. Nuclear amination catalyzed by fungal laccases: Reaction products of p-hydroquinones and primary aromatic amines. J. Org. Chem. 70, 2002-2008. https://doi.org/10.1021/jo048454s

Osiadacz, J., Al-Adhami, A.J.H., Bajraszewska, D., Fischer, P., Peczyñska-Czoch, W., 1999. On the use of Trametes versicolor laccase for the conversion of 4-methyl-3-hydroxyanthranilic acid to actinocin chromophore. J. Biotechnol. 72, 141-149. https://doi.org/10.1016/S0168-1656(99)00100-5

Osma, J.F., Toca-Herrera, J.L., Rodríguez-Couto, S., 2010. Uses of laccases in the food industry. Enzyme Res. 2010. https://doi.org/10.4061/2010/918761

Otterbein, L., Record, E., Longhi, S., Asther, M., Moukha, S., 2000. Molecular cloning of the cDNA encoding laccase from Pycnoporus cinnabarinus I-937 and expression in Pichia pastoris. Eur. J. Biochem. 267, 1619-1625. https://doi.org/10.1046/j.1432-1327.2000.01166.x

Otzen, D., 2011. Protein-surfactant interactions: A tale of many states. Biochim. Biophys. Acta - Proteins Proteomics 1814, 562-591. https://doi.org/10.1016/j.bbapap.2011.03.003

Pardo, I., Camarero, S., 2015a. Exploring the oxidation of lignin-derived phenols by a library of laccase mutants. Molecules 20, 15929-15943. https://doi.org/10.3390/molecules200915929

Pardo, I., Camarero, S., 2015b. Laccase engineering by rational and evolutionary design. Cell. Mol. Life Sci. 72, 897910. https://doi.org/10.1007/s00018-014-1824-8

Pardo, I., Vicente, A.I., Mate, D.M., Alcalde, M., Camarero, S., 2012. Development of chimeric laccases by directed evolution. Biotechnol. Bioeng. 109, 2978-2986. https://doi.org/10.1002/bit.24588

Pezzella, C., Giacobbe, S., Giacobelli, V.G., Guarino, L., Kylic, S., Sener, M., Sannia, G., Piscitelli, A., 2016. Green routes towards industrial textile dyeing: A laccase based approach. J. Mol. Catal. B Enzym. 134, 274-279. https://doi.org/10.1016/j.molcatb.2016.11.016

Pezzella, C., Giacobelli, V.G., Lettera, V., Olivieri, G., Cicatiello, P., Sannia, G., Piscitelli, A., 2017. A step forward in laccase exploitation: Recombinant production and evaluation of techno-economic feasibility of the process. J. Biotechnol. 259, 175-181. https://doi.org/10.1016/j.jbiotec.2017.07.022

Pezzella, C., Guarino, L., Piscitelli, A., 2015. How to enjoy laccases. Cell. Mol. Life Sci. 72, 923-940. https://doi.org/10.1007/s00018-014-1823-9

Piontek, K., Antorini, M., Choinowski, T., 2002. Crystal structure of a laccase from the fungus Trametes versicolor at 1.90-A resolution containing a full complement of coppers. J. Biol. Chem. 277, 37663-37669. https://doi.org/10.1074/jbc.M204571200

Polak, J., Jarosz-Wilkolazka, A., 2012. Fungal laccases as green catalysts for dye synthesis. Process Biochem. 47, 1295-1307. https://doi.org/10.1016/j.procbio.2012.05.006

Record, E., Punt, P.J., Chamkha, M., Labat, M., Van Den Hondel, C.A.M.J.J.M.J.J., Asther, M., 2002. Expression of the Pycnoporus cinnabarinus laccase gene in Aspergillus niger and characterization of the recombinant enzyme. Eur. J. Biochem. 269, 602-609. https://doi.org/10.1046/j.0014-2956.2001.02690.x

Rico, A., Rencoret, J., Del Río, J.C., Martínez, A.T., Gutiérrez, A., 2014. Pretreatment with laccase and a phenolic mediator degrades lignin and enhances saccharification of Eucalyptus feedstock. Biotechnol. Biofuels 7, 114. https://doi.org/10.1186/1754-6834-7-6

Rivera-Hoyos, C.M., Morales-Álvarez, E.D., Poutou-Piñales, R.A., Pedroza-Rodríguez, A.M., RodrÍguez-Vázquez, R., Delgado-Boada, J.M., 2013. Fungal laccases. Fungal Biol. Rev. 27, 67-82. 
https://doi.org/10.1016/j.fbr.2013.07.001

Rodríguez-Delgado, M.M., Alemán-Nava, G.S., Rodríguez-Delgado, J.M., Dieck-Assad, G., Martínez-Chapa, S.O., Barceló, D., Parra, R., 2015. Laccase-based biosensors for detection of phenolic compounds. TrAC - Trends Anal. Chem. 74, 21-45. https://doi.org/10.1016/j.trac.2015.05.008

Rodríguez-Padrón, D., Puente-Santiago, A.R., Caballero, A., Balu, A.M., Romero, A.A., Luque, R., 2018. Highly efficient direct oxygen electro-reduction by partially unfolded laccases immobilized on waste-derived magnetically separable nanoparticles. Nanoscale 10, 3961-3968. https://doi.org/10.1039/c8nr00512e

Rostami, A., Mohammadi, B., Shokri, Z., Saadati, S., 2018. Laccase-TEMPO as an efficient catalyst system for metaland halogen-free aerobic oxidation of thioethers to sulfoxides in aqueous media at ambient conditions. Catal. Commun. 111, 59-63. https://doi.org/10.1016/j.catcom.2018.03.032

Sagui, F., Chirivì, C., Fontana, G., Nicotra, S., Passarella, D., Riva, S., Danieli, B., 2009. Laccase-catalyzed coupling of catharanthine and vindoline: an efficient approach to the bisindole alkaloid anhydrovinblastine. Tetrahedron 65, 312-317. https://doi.org/10.1016/j.tet.2008.10.064

Salony, Garg, N., Baranwal, R., Chhabra, M., Mishra, S., Chaudhuri, T.K., Bisaria, V.S., 2008. Laccase of Cyathus bulleri: structural, catalytic characterization and expression in Escherichia coli. Biochim. Biophys. Acta - Proteins Proteomics 1784, 259-268. https://doi.org/10.1016/j.bbapap.2007.11.006

Sapurina, I., Stejskal, J., 2008. The mechanism of the oxidative polymerization of aniline and the formation of supramolecular polyaniline structures. Polym. Int. https://doi.org/10.1002/pi.2476

Schultz, A., Jonas, U., Hammer, E., Schauer, F., 2001. Dehalogenation of chlorinated hydroxybiphenyls by fungal laccase. Appl. Environ. Microbiol. 67, 4377-4381. https://doi.org/10.1128/AEM.67.9.4377-4381.2001

Sekretaryova, A., Jones, S.M., Solomon, E.I., 2019. 02 Reduction to water by high potential multicopper oxidases: contributions of the T1 copper site potential and the local environment of the trinuclear copper cluster. J. Am. Chem. Soc. 141, 11304-11314. https://doi.org/10.1021/jacs.9b05230

Sekretaryova, A.N., Volkov, A. V., Zozoulenko, I. V., Turner, A.P.F., Vagin, M.Y., Eriksson, M., 2016. Total phenol analysis of weakly supported water using a laccase-based microband biosensor. Anal. Chim. Acta 907, 45-53. https://doi.org/10.1016/j.aca.2015.12.006

Sgalla, S., Fabrizi, G., Cacchi, S., Macone, A., Bonamore, A., Boffi, A., 2007. Horseradish peroxidase in ionic liquids. Reactions with water insoluble phenolic substrates. J. Mol. Catal. B Enzym. 44, 144-148. https://doi.org/10.1016/j.molcatb.2006.10.002

Shim, E., Su, J., Noro, J., Teixeira, M.A., Cavaco-Paulo, A., Silva, C., Kim, H.R., 2019. Conductive bacterial cellulose by in situ laccase polymerization of aniline. PLoS One 14, 1-14. https://doi.org/10.1371/journal.pone.0214546

Shumakovich, G., Streltsov, A., Gorshina, E., Rusinova, T., Kurova, V., Vasil'eva, I., Otrokhov, G., Morozova, O., Yaropolov, A., 2011. Laccase-catalyzed oxidative polymerization of aniline dimer (N-phenyl-1,4phenylenediamine) in aqueous micellar solution of sodium dodecylbenzenesulfonate. J. Mol. Catal. B Enzym. 69, 83-88. https://doi.org/10.1016/j.molcatb.2011.01.016

Streltsov, A. V., Shumakovich, G.P., Morozova, O. V., Gorbacheva, M.A., Yaropolov, A.I., 2008. Micellar laccasecatalyzed synthesis of electroconductive polyaniline. Appl. Biochem. Microbiol. 44, 264-270. https://doi.org/10.1134/S000368380803006X

Su, J., Noro, J., Fu, J., Wang, Q., Silva, C., Cavaco-Paulo, A., 2019a. Coloured and low conductive fabrics by in situ $\begin{array}{lllll}\text { laccase-catalysed } & \text { polymerization. } & \text { Process } & \text { 77-84. }\end{array}$ https://doi.org/10.1016/j.procbio.2018.11.007

Su, J., Noro, J., Silva, S., Fu, J., Wang, Q., Ribeiro, A., Silva, C., Cavaco-Paulo, A., 2019b. Antimicrobial coating of textiles by laccase in situ polymerization of catechol and p-phenylenediamine. React. Funct. Polym. 136, 25-33. https://doi.org/10.1016/j.reactfunctpolym.2018.11.015

Su, J., Shim, E., Noro, J., Fu, J., Wang, Q., Kim, H.R., Silva, C., Cavaco-Paulo, A., 2018. Conductive cotton by in situ laccase-polymerization of aniline. Polymers (Basel). 10, 1-13. https://doi.org/10.3390/polym10091023 
Su, X., Schmitz, G., Zhang, M., Mackie, R.I., Cann, I.K.O., 2012. Heterologous gene expression in filamentous fungi, advances in applied microbiology. Elsevier. https://doi.org/10.1016/B978-0-12-394382-8.00001-0

Teng, C., Wu, S., Gong, G., 2019. Bio-removal of phenanthrene, 9-fluorenone and anthracene-9,10-dione by laccase from Aspergillus niger in waste cooking oils. Food Control 105, 219-225. https://doi.org/10.1016/j.foodcont.2019.06.015

Tian, Q., Dou, X., Huang, L., Wang, L., Meng, D., Zhai, L., Shen, Y., You, C., Guan, Z., Liao, X., 2020. Characterization of a robust cold-adapted and thermostable laccase from Pycnoporus sp. SYBC-L10 with a strong ability for the degradation of tetracycline and oxytetracycline by laccase-mediated oxidation. J. Hazard. Mater. 382, 121084. https://doi.org/10.1016/j.jhazmat.2019.121084

Tranchimand, S., Tron, T., Gaudin, C., Iacazio, G., 2006. Synthesis of bis-lactone lignans through laccase catalysis. J. Mol. Catal. B Enzym. 42, 27-31. https://doi.org/10.1016/j.molcatb.2006.06.003

Vasil'eva, I.S., Morozova, O. V., Shumakovich, G.P., Iaropolov, A.I., 2008. Synthesis of electroconductive polyaniline using immobilized laccase. Appl. Biochem. Microbiol. 45, 33-37. https://doi.org/10.1134/S0003683809010050

Vittorio, O., Cojoc, M., Curcio, M., Spizzirri, U.G., Hampel, S., Nicoletta, F.P., Iemma, F., Dubrovska, A., Kavallaris, M., Cirillo, G., 2016. Polyphenol conjugates by immobilized laccase: the green synthesis of dextran-catechin. Macromol. Chem. Phys. 217, 1488-1492. https://doi.org/10.1002/macp.201600046

Wang, B., Wang, X., Tian, Y., Li, Z., Gao, J., Yan, Y., Peng, R., Yao, Q., 2016. Heterologous expression and characterization of a laccase from Laccaria bicolor in Pichia pastoris. Biotechnol. Biotechnol. Equip. 30, 6368. https://doi.org/10.1080/13102818.2015.1104261

Wellington, K.W., Govindjee, V.P., Steenkamp, P., 2018. A laccase-catalysed synthesis of triaminated cyclohexa-2,4dienones from catechol. J. Catal. 368, 306-314. https://doi.org/10.1016/j.jcat.2018.10.014

Widsten, P., Kandelbauer, A., 2008. Laccase applications in the forest products industry: A review. Enzyme Microb. Technol. 42, 293-307. https://doi.org/10.1016/j.enzmictec.2007.12.003

$\mathrm{Xu}$, F., 2002. Laccases, in: Encyclopedia of Bioprocess Technology: Fermentation, Biocatalysis, Bioseparation. https://doi.org/10.1002/0471250589.ebt125

Xu, G., Wu, Y., Zhang, Y., Fang, W., Xiao, Y., Fang, Z., 2019. Role of N-glycosylation on the specific activity of a Coprinopsis cinerea laccase Lcc9 expressed in Pichia pastoris. J. Biosci. Bioeng. 128, 518-524. https://doi.org/10.1016/j.jbiosc.2019.05.004

$\mathrm{Xu}$, Q., Fu, Y., Gao, Y., Qin, M., 2009. Performance and efficiency of old newspaper deinking by combining cellulase/hemicellulase with laccase-violuric acid system. Waste Manag. 29, 1486-1490. https://doi.org/10.1016/j.wasman.2008.10.007

Yoon, J., Solomon, E.I., 2007. Electronic Structure of the Peroxy Intermediate and Its Correlation to the Native Intermediate in the Multicopper Oxidases: Insights into the Reductive Cleavage of the 0-0 Bond. J. Am. Chem. Soc. 129, 13127-13136. https://doi.org/10.1021/ja073947a

Yoshida, H., 1883. Chemistry of Lacquer (Urushi). J. Chem. Soc. 43, 472-486.

Zerva, A., Koutroufini, E., Kostopoulou, I., Detsi, A., Topakas, E., 2019. A novel thermophilic laccase-like multicopper oxidase from Thermothelomyces thermophila and its application in the oxidative cyclization of $2^{\prime}, 3,4$ trihydroxychalcone. N. Biotechnol. 49, 10-18. https://doi.org/https://doi.org/10.1016/j.nbt.2018.12.001

Zhang, J., Zou, F., Yu, X., Huang, X., Qu, Y., 2014. Ionic liquid improves the laccase-catalyzed synthesis of watersoluble conducting polyaniline. Colloid Polym. Sci. 292, 2549-2554. https://doi.org/10.1007/s00396-014$3301-1$

Zhang, T., Bai, R., Shen, J., Wang, Q., Wang, P., Yuan, J., Fan, X., 2018. Laccase-catalyzed polymerization of diaminobenzenesulfonic acid for $\mathrm{pH}$-responsive color-changing and conductive wool fabrics. Text. Res. J. 88, 2258-2266. https://doi.org/10.1177/0040517517720497 
Zhang, Zhen, Zhang, Zhongming, Hu, Y., Liu, J., Ni, H., Li, L., 2017. Phenol biosensor based on glassy carbon electrode directly absorbed Escherichia coli cells with surface-displayed bacterial laccase. Procedia Technol. 27, 137138. https://doi.org/10.1016/j.protcy.2017.04.060 


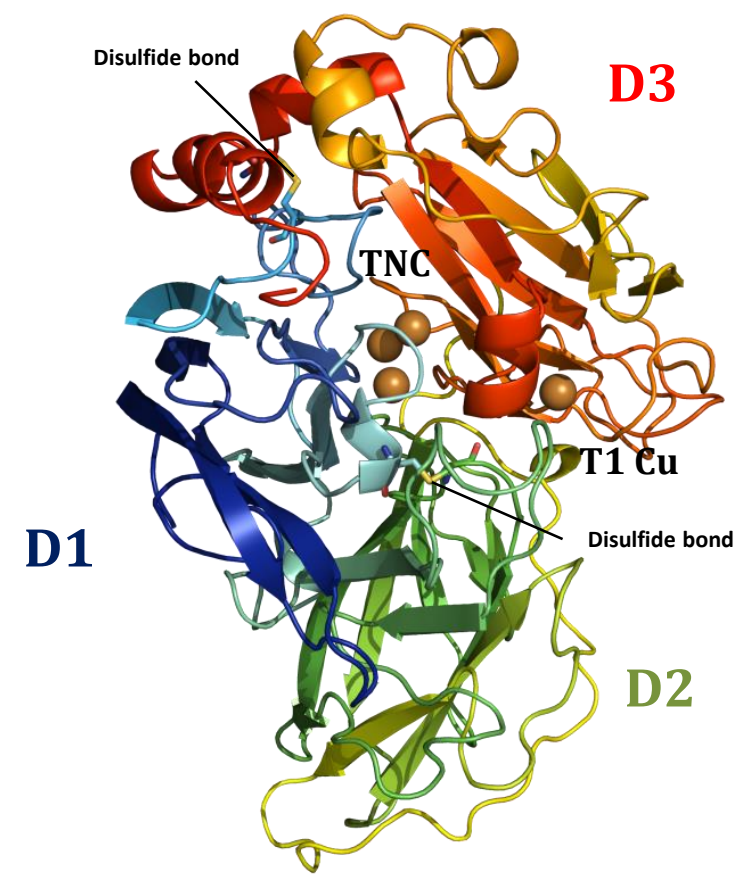

Figure 1. Cartoon representation of the crystal structure of Pycnoporus cinnabarinus laccase (PDB 2XYB), showing the three cupredoxin domain (D1-D3) folding, the catalytic coppers as spheres, and the two disulfide bridges in yellow. TNC refers to trinuclear cluster where oxygen is reduced to water and $\mathrm{T} 1 \mathrm{Cu}$ is the copper responsible for substrate oxidation. 


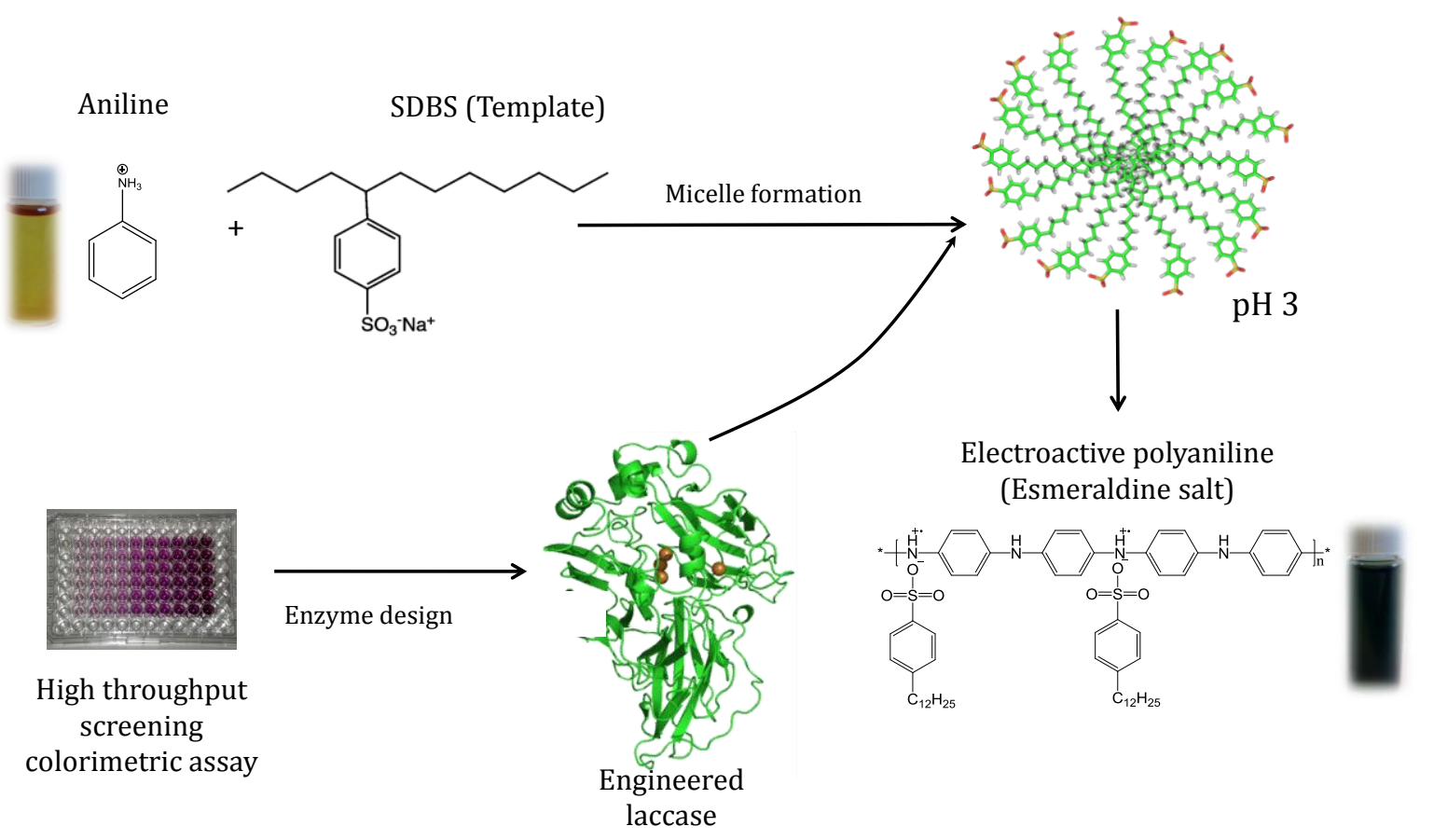

Figure 6. Scheme of the synthesis of conductive PANI carried out in our lab using an engineered laccase and sodium dodecylbenzenesulfonate (SDBS) as template. 


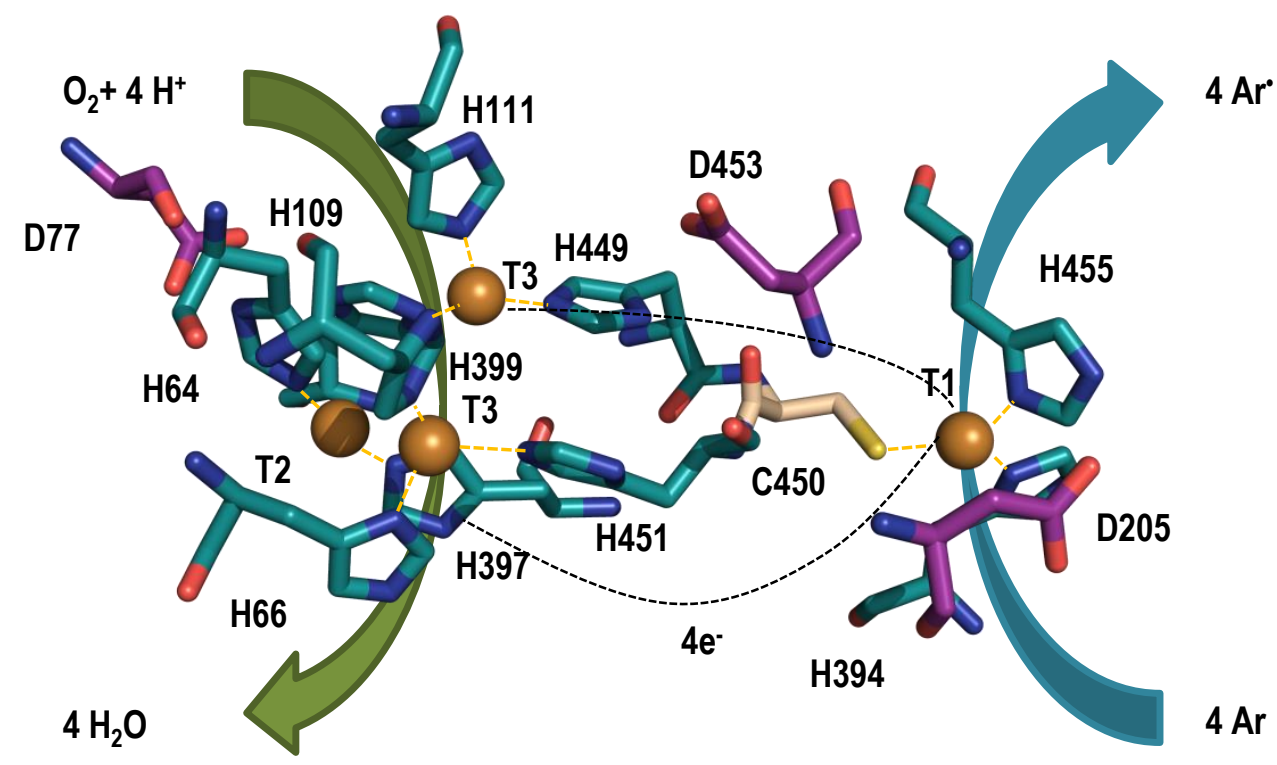

Figure 2. Catalytic site and catalytic mechanism of laccase. His (blue) and Cys (wheat) residues coordinating the catalytic coppers and conserved Asp residues involved in proton transfer (purple) are shown. The four coppers are depicted as spheres. Residues coordinating the four catalytic coppers and electron transfer from $\mathrm{T} 1$ site to the tri-nuclear cluster through the triplet $\mathrm{H}-\mathrm{C}$ $\mathrm{H}$ are shown based on PM1 laccase structure (PDB: 5ANH). 


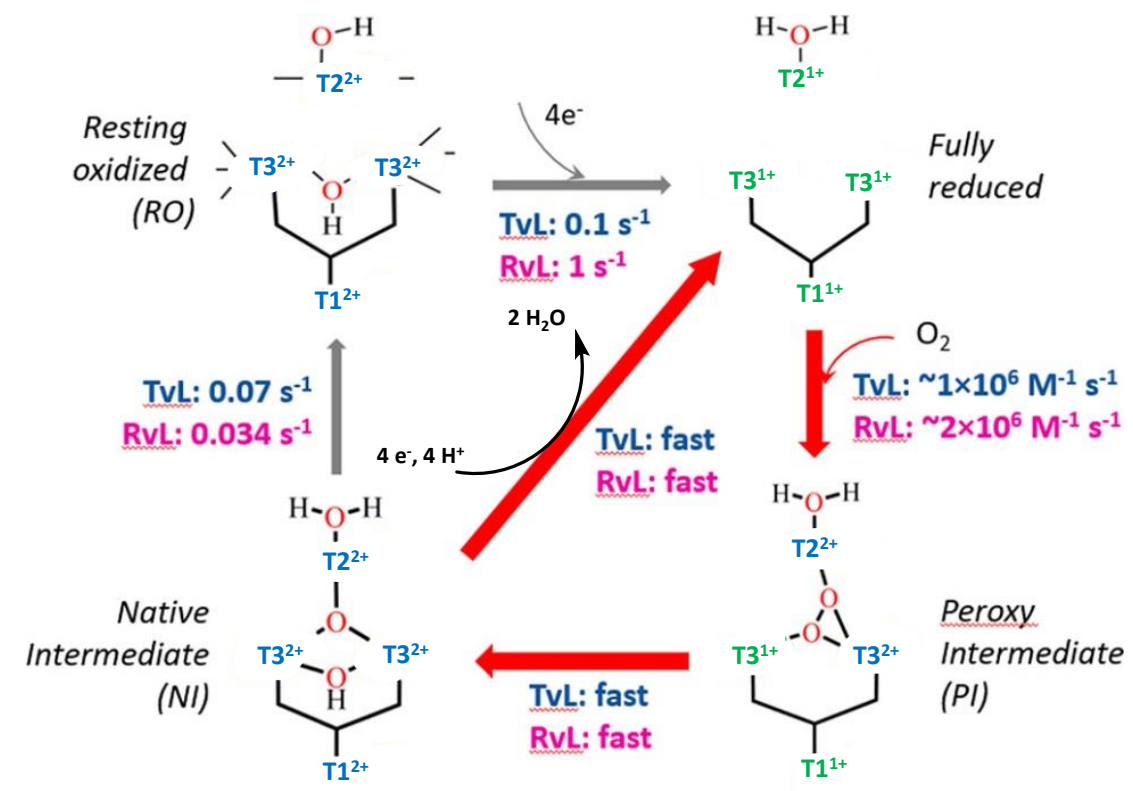

Figure 3. Redox mechanism of the high redox potential laccase from T. versicolor (TvL) vs the low redox potential laccase from Rhus vernicifera (RvL) (adapted with permission from Sekretaryova et al., 2019, American Chemical Society). 

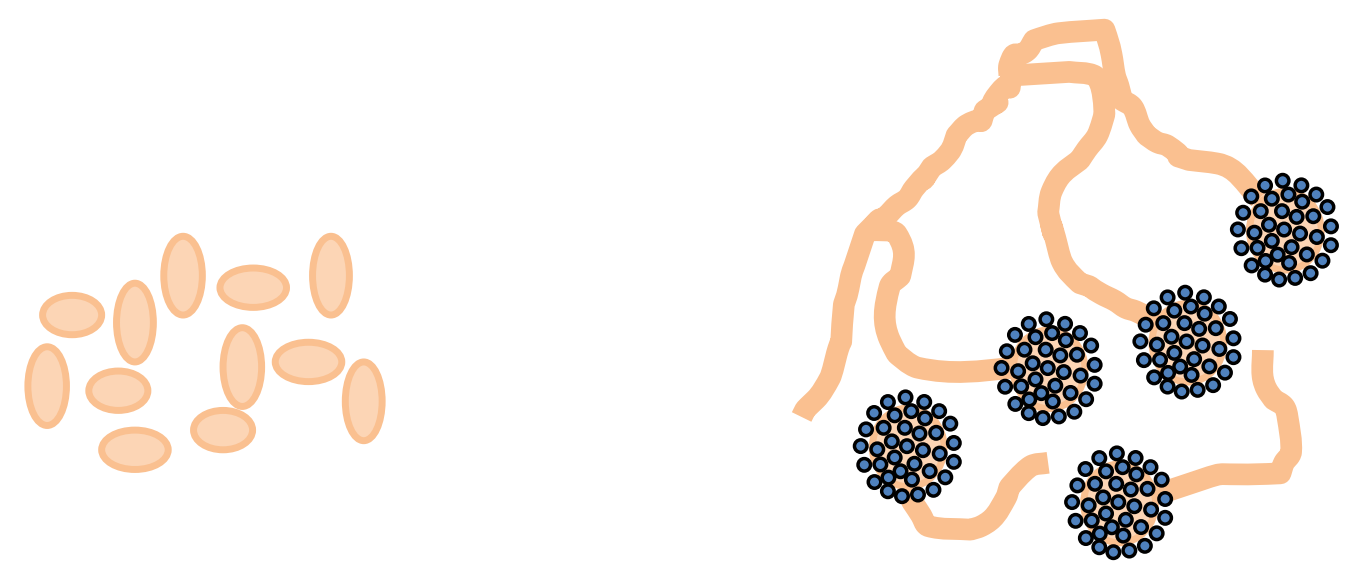

\section{YEAST}

ADVANTAGES

- Lots of strains and vectors

- Easy genetic manipulation

DRAWBACKS

- Frequent hyperglycosylation

- Lower secretion yields compared with

filamentous fungi
FILAMENTOUS ASCOMYCETES

ADVANTAGES

- High production yields

DRAWBACKS

- High variability of the enzyme produced

Figure 4. Comparison of yeast and filamentous ascomycetes as heterologous hosts for laccase production. 


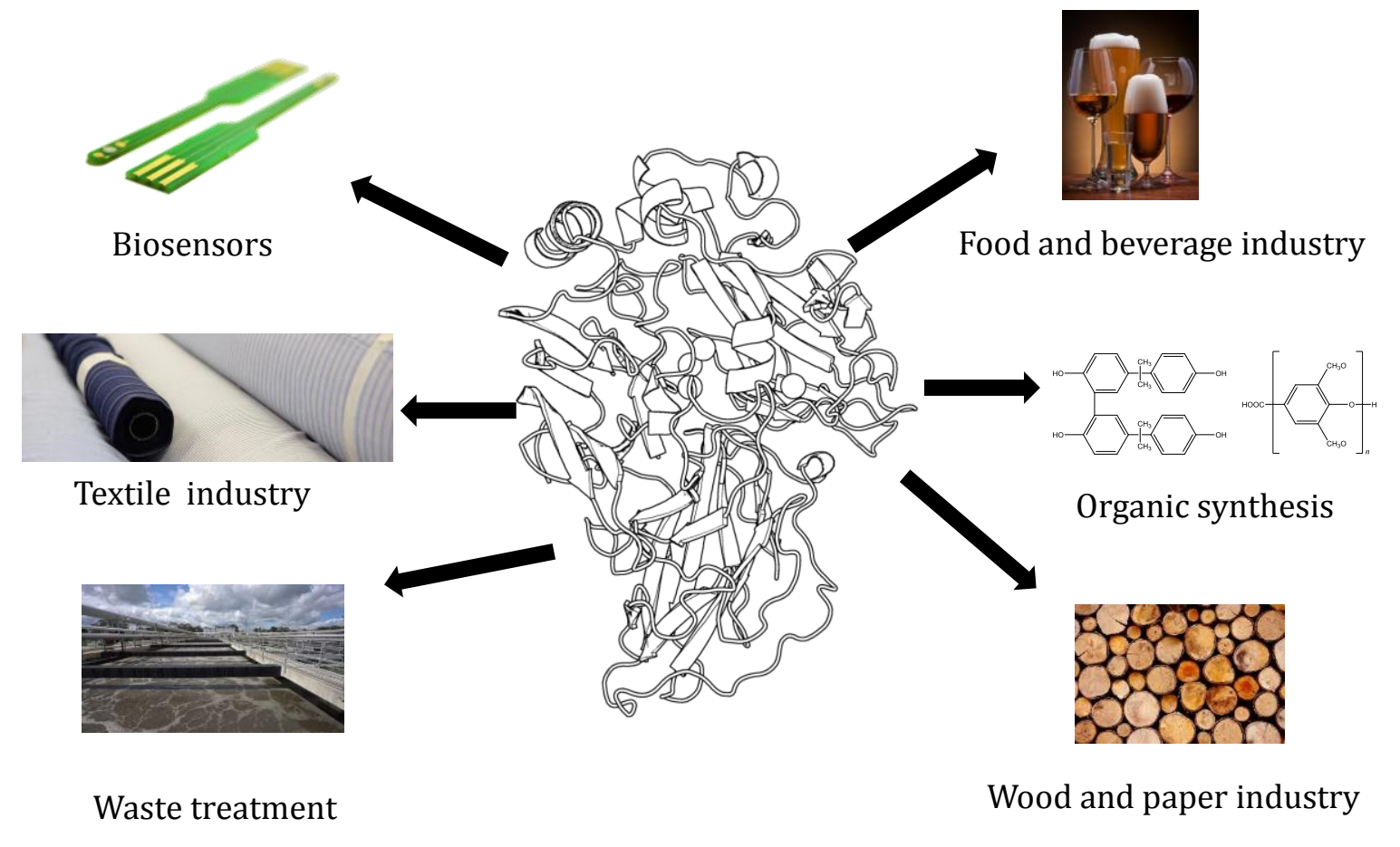

Figure 5. Examples of laccase applications. 